\title{
PROCESSAMENTO MÍNIMO DE TANGOR 'MURCOTT': \\ CARACTERIZAÇÃO FISIOLÓGICA E RECOBRIMENTOS COMESTÍVEIS
}

RAQUEL CAPISTRANO MOREIRA

Dissertação apresentada à Escola Superior de Agricultura "Luiz de Queiroz", Universidade de São Paulo, para obtenção do título de Mestre em Agronomia, Área de Concentração: Fitotecnia.

PIRA CICABA

Estado de São Paulo - Brasil

Dezembro - 2004 


\section{PROCESSAMENTO MÍNIMO DE TANGOR 'MURCOTT': \\ CARACTERIZAÇÃO FISIOLÓGICA E RECOBRIMENTOS COMESTÍVEIS}

\section{RAQUEL CAPISTRANO MOREIRA}

Engenheiro Agrônomo

Orientador: Prof Dr. ANGELO PEDRO JACOMINO

Dissertação apresentada à Escola
Superior de Agricultura "Luiz de
Queiroz", Universidade de São
Paulo, para obtenção do título de
Mestre em Agronomia, Área de
Concentração: Fitotecnia.

PIR A C I C A B A

Estado de São Paulo - Brasil

Dezembro - 2004 
Dados I nt ernacionai s de Cat al ogação na Publi cação ( CI P) DI VI SÃO DE BI BLI OTECA E DOCUMENTAÇÃO - ESALQI USP

Moreira, Raquel Capistrano

Processamento mínimo de tangor 'Murcott' : caracterização fisiológica e recobrimentos comestíveis / Raquel Capistrano Moreira. - - Piracicaba, 2004.

84 p. : il.

Dissertação (Mestrado) - - Escola Superior de Agricultura Luiz de Queiroz, 2004.

Bibliografia.

1. Armazenagem em atmosfera modificada 2. Bioquímica de alimentos 3. Etileno 4. Fisiologia pós-colheita 5. Fruta cítrica 6 . Microbiologia de alimentos 7 . Processamento de alimento 8. Respiração vegetal I. Título

CDD 634.3

"Permi tida a cópia total ou parcial deste documento, desde que citada a fonte - O aut or" 
Aos meus pais: Sinésio e Ana Lúcia, pela confiança, apoio, exemplo e compreensão.

DEDICO.

Às minhas irmãs: Renata e Flávia,

pela amizade e incentivo.

Ao meu afilhado Marco Antonio, por

ter trazido tanta alegria com sua

presença.

OFEREÇO. 


\section{AGRADECIMENTOS}

A Deus, por iluminar sempre o meu caminho e pela oportunidade de realizar este trabalho.

À Comissão do Programa de Pós-Graduação em Fitotecnia pela oportunidade de realização do curso de Mestrado.

Ao Conselho Nacional de Desenvolvimento Científico e Tecnológico (CNPq), pela concessão da bolsa.

Ao Prof. Dr. Angelo Pedro Jacomino, pela orientação, incentivo, confiança e dedicação.

Ao Prof. Dr. Ricardo Alfredo Kluge, pelas sugestões e apoio durante o curso.

Ao Prof. Dr. Cláudio Rosa Gallo e à técnica de laboratório Cecília Helena Nogueira pela atenção e apoio na realização da etapa microbiológica.

Ao Prof. Dr. Paulo César Tavares de Melo pela oportunidade de monitoria e por seu incentivo.

Ao Prof. Dr. Enes Furlani Jr. por ter me despertado para a pesquisa científica e por seus constantes ensinamentos. 
À querida colega de Pós-Graduação Maria Cecília de Arruda, por seus ensinamentos, ajuda e amizade.

Ao $\mathrm{Eng}^{\circ} \mathrm{Agr}^{\circ}$ Marcos José Trevisan, por sua amizade e também pelo total apoio e entrega ao Laboratório de Pós-Colheita de Produtos Hortícolas, sem o qual teria sido muito mais árdua a tarefa de concluir este trabalho.

Às estagiárias Ana Luiza Pinheiro (Eliotti) e Michele Lochoski (Lixa), pela ajuda com os experimentos e pelos momentos de descontração.

À Dra. Ana Cláudia Carraro Alleoni, por sua imensa ajuda com os recobrimentos protéicos.

Aos demais estagiários do Laboratório de Pós-Colheita de Produtos Hortícolas: Alexandra (Primavera), Angela (Feitc-êra), Gustavo (Sardiña), Márcia (Cindi), Ana Elisa (Pulenta) e Viviani (Cometa), pela ajuda com os experimentos e agradáveis momentos de convivência.

Aos demais alunos de Pós-Graduação do grupo de Pós-Colheita: Daniela, Fabiana, Flávia, Ilana, Juan, Maria Carolina e Maria Luiza, pela convivência e troca de informações.

À Ouro do Brasil Comércio de Frutas Ltda., em especial ao Pedro, Álvaro, Edgar e Marcela, pelo fornecimento de frutos para a realização destes trabalhos.

À Gelita do Brasil Ltda. pelo fornecimento da gelatina.

À Megh Indústria e Comércio, pelo fornecimento da emulsão de parafina. 
Aos funcionários do Departamento de Produção Vegetal, em especial, Aparecido, Bete, Célia, Davi, Éder, D. Helena e Hodair.

À secretária do PPG em Fitotecnia Luciane Aparecida Lopes, por sua competência, apoio e amizade.

Aos amigos Ana Helena, Beatriz, João Paulo, Juliano, Luciana, Márcia (prima querida) e Rafael, pelo companheirismo, apoio e momentos de diversão.

Aos colegas contemporâneos do PPG em Fitotecnia pela agradável convivência.

A todos que de alguma forma contribuíram para a realização deste trabalho. 


\section{SUMÁRIO}

Página

RESUMO …........................................................................... ix

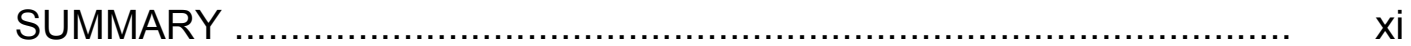

1 INTRODUÇÃO ........................................................................... 1

2 REVISÃO DE LITERATURA …................................................ 3

2.1 Aspectos gerais sobre tangor 'Murcott' ....................................... 3



2.3 Fatores que influenciam a qualidade dos produtos minimamente 5 processados

2.3.1 Temperatura ............................................................... 5

2.3.2 Umidade relativa ............................................................ 7

2.3.3 Atmosfera modificada .................................................... 8

2.3.4 Aspectos fisiológicos e bioquímicos ........................................ 9

2.3.5 Aspectos microbiológicos ................................................... 10

2.4 Recobrimentos comestíveis ................................................. 11

3 ATIVIDADE RESPIRATÓRIA E PRODUÇÃO DE ETILENO DE 14 TANGOR 'MURCOTT' EM FUNÇÃO DO NÍVEL DE PROCESSAMENTO MÍNIMO E DA TEMPERATURA DE ARMAZENAMENTO

Resumo

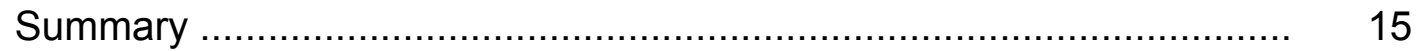

3.1 Introdução....................................................................... 16

3.2 Material e métodos ............................................................ 17

3.3 Resultados e discussão ............................................................ 19 
3.3.1 Atividade respiratória em função da temperatura de 19 armazenamento

3.3.2 Atividade respiratória em função do nível de processamento mínimo

3.3.3 Quocientes de temperatura $\left(Q_{10}\right)$.... 27

3.4 Conclusões 30

4 RECOBRIMENTOS COMESTÍVEIS PARA TANGOR 'MURCOTT' 31 MINIMAMENTE PROCESSADO

Resumo 31

Summary 32

4.1 Introdução 33

4.2 Material e métodos 34

4.3 Resultados e discussão 42

4.3.1 Taxa respiratória 42

4.3.2 Análises físico-químicas. 44

4.3.2.1 Ácido ascórbico 44

4.3.2.2 Sólidos solúveis 46

4.3.2.3 Acidez titulável e "ratio" 47

4.3.2.4 Perda de massa fresca .................................................. 51

4.3.2.5 Coloração ...................................................................... 52

4.3.3 Análises microbiológicas ................................................ 54

4.3.4 Análise sensorial ........................................................... 58

4.4 Considerações gerais ......................................................... 59

4.5 Conclusões ..................................................................... 60

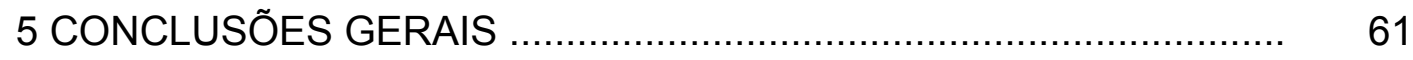

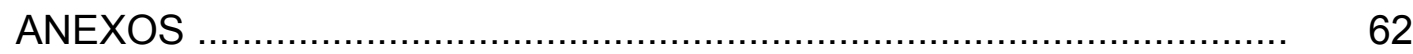

REFERÊNCIAS BIBLIOGRÁFICAS ............................................. 65 


\title{
PROCESSAMENTO MÍNIMO DE TANGOR 'MURCOTT': CARACTERIZAÇÃO FISIOLÓGICA E RECOBRIMENTOS COMESTÍVEIS
}

\author{
Autora: RAQUEL CAPISTRANO MOREIRA \\ Orientador: Prof. Dr. ANGELO PEDRO JACOMINO
}

\section{RESUMO}

Os objetivos deste trabalho foram determinar o efeito do processamento mínimo e da temperatura de armazenamento na fisiologia do tangor 'Murcott' minimamente processado e determinar os recobrimentos comestíveis que promovam a manutenção da qualidade microbiológica, sensorial e físicoquímica de tangor 'Murcott' minimamente processado. No primeira etapa foram testados dois níveis de processamento (tangores inteiros sem a casca e tangores em gomos) e cinco temperaturas de armazenamento $\left(1^{\circ}, 6^{\circ}, 11^{\circ}, 21^{\circ} \mathrm{e}\right.$ $31^{\circ} \mathrm{C}$ ). Frutos intactos foram utilizados como controle. No segundo experimento os tangores em gomos foram tratados com diversos recobrimentos comestíveis e armazenados sob duas temperaturas $\left(6^{\circ}\right.$ e $\left.12^{\circ} \mathrm{C}\right)$. Os recobrimentos utilizados foram: gelatina a $4 \% \mathrm{p} / \mathrm{p}$, gelatina a $8 \% \mathrm{p} / \mathrm{p}$, concentrado protéico de soro de leite a $8 \% \mathrm{p} / \mathrm{p}$ e emulsão a base de parafina. Tangores sem recobrimentos foram utilizados como controle. No primeiro experimento foram determinadas as taxas respiratórias e de produção de etileno a cada hora durante as 10 primeiras horas após o processamento e, em seguida, a cada 24 horas por sete dias. Determinaram-se também os quocientes de temperatura $\left(Q_{10}\right)$. No segundo experimento determinaram-se: as características físico-químicas a cada dois dias por um período de seis dias; a taxa respiratória diariamente por oito dias; as características microbiológicas no quarto e sétimo dias após o 
processamento e as características sensoriais no quarto dia após o processamento. Os níveis de etileno foram baixos e inconstantes ao longo do tempo de avaliação. O aumento da temperatura de armazenamento e o nível de processamento mínimo influenciaram a taxa respiratória. Os recobrimentos comestíveis foram pouco efetivos na redução da taxa respiratória e na manutenção das características físico-químicas, microbiológicas e sensoriais de gomos de tangor 'Murcott'. 


\title{
FRESH-CUT TANGOR 'MURCOTT': PHYSIOLOGICAL CHARACTERIZATION AND EDIBLE COATINGS
}

\author{
Author: RAQUEL CAPISTRANO MOREIRA \\ Adviser: Prof. Dr. ANGELO PEDRO JACOMINO
}

\section{SUMMARY}

The objectives of this work were to determine the effect of minimally processing and the storage temperature on the physiology of fresh-cut tangor 'Murcott' and to determine the edible coatings that maintain the microbiological, sensorial and physico-chemical qualities of fresh-cut tangor 'Murcott'. In the first experiment two processing levels (peeled fruits and segments) and five storage temperatures $\left(1^{\circ}, 6^{\circ}, 11^{\circ}, 21^{\circ}\right.$ and $\left.31^{\circ} \mathrm{C}\right)$ were tested. Whole fruits were used as control. In the second experiment the segments were treated with several edible coatings and stored under two temperatures $\left(6^{\circ}\right.$ and $\left.12^{\circ} \mathrm{C}\right)$. The edible coatings were: gelatin $4 \% \mathrm{w} / \mathrm{w}$, gelatin $8 \% \mathrm{w} / \mathrm{w}$, whey protein $8 \% \mathrm{w} / \mathrm{w}$ and paraffin wax emulsion. Segments without recovering were used as control. In the first experiment the respiratory rate and the ethylene production were determined every hour for 10 hours and then, every day for 7 days. The temperature quotients $\left(Q_{10}\right)$ were also determined. In the second experiment were determined: the physico-chemical properties every two day for six days; the respiratory rate daily for eight days; the microbiological analysis on the fourth and seventh days of storage; and the sensorial analysis on the fourth day of storage. The storage temperature and the processing level did influence the respiratory rate. The ethylene levels were low and inconstant during the study. The edible coatings were little effective on reducing the respiratory rate and on 
maintaining the physico-chemical, microbiological and sensorial properties of fresh-cut tangor 'Murcott'. 


\section{INTRODUÇÃO}

O consumo de produtos minimamente processados tem aumentado no cenário mundial. Em 1997, a venda destes produtos nos EUA alcançou US\$7,9 bilhões. No Brasil, calcula-se que no ano de 1998, o setor tenha movimentado R\$ 450 milhões (FNP, 2000; Moretti, 1999).

Nos últimos anos tem se verificado um aumento na participação das mulheres no mercado de trabalho, o que reduz o tempo disponível para o preparo das refeições. Aliado a este fato, a busca por uma alimentação cada vez mais saudável e conveniente e a redução do tamanho das famílias resulta na procura de alimentos práticos, saudáveis, que reduzam as perdas e que tenham alta qualidade nutricional e organoléptica. A indústria de alimentos responde a esta demanda com a oferta de produtos hortícolas prontos para o consumo, os minimamente processados.

O processamento mínimo de produtos hortícolas normalmente é realizado através das operações de lavagem, descascamento, fatiamento, corte ou retalhamento, sanitização e embalagem, entre outras, a depender do produto (Wiley, 1994).

Frutas e hortaliças minimamente processadas apresentam metabolismo elevado, devido aos danos mecânicos causados pelas operações de descascamento e corte. A injúria causada pelo corte promove aumento na produção de etileno e na taxa respiratória, favorecendo, assim, a rápida deterioração do vegetal (Wiley, 1994).

Devido à alta perecibilidade dos produtos minimamente processados, os fatores relacionados à qualidade destes produtos devem ser observados. De 
acordo com Watada et al. (1996), a temperatura, a embalagem, a umidade relativa e os microrganismos são os principais fatores que afetam a qualidade dos produtos minimamente processados.

O controle da temperatura é a técnica mais útil e importante para minimizar as injúrias provocadas pelo processamento mínimo de frutas e hortaliças (Brecht, 1995).

A utilização de recobrimentos comestíveis é uma das formas de criar uma barreira semipermeável a gases e vapor d'água, reduzindo, assim, a taxa respiratória e a perda de água, garantindo o aumento da vida de prateleira de produtos minimamente processados (Baldwin et al., 1995b).

O tangor 'Murcott' possui ótima aceitação no mercado para o consumo in natura, porém sua casca é relativamente fina e bastante aderida ao fruto, o que dificulta seu descascamento por parte dos consumidores, tendo, assim, um grande potencial de ser comercializado sob a forma de produto minimamente processado. Desta forma, este trabalho teve como objetivos determinar o efeito do processamento mínimo e da temperatura de armazenamento na fisiologia do tangor 'Murcott' minimamente processado e determinar os recobrimentos comestíveis que promovam a manutenção da qualidade microbiológica, sensorial e físico-química de tangor 'Murcott' minimamente processado. 


\section{REVISÃO DE LITERATURA}

\subsection{Aspectos gerais sobre tangor 'Murcott'}

O tangor 'Murcott' pertence à Família Rutaceae, é um híbrido de tangerina (Citrus reticulata Blanco) com laranja doce (Citrus sinensis [L.] Osb.) originado de um pomar abandonado do Departamento de Agricultura dos Estados Unidos, e que foi propagado pela primeira vez por Charles Murcott Smith. Suas árvores e frutos possuem diversas características de uma tangerina típica, tais como: alto vigor, hábito de crescimento ereto e folhas lanceoladas entre outras (Davies \& Albrigo, 1994).

Seus frutos são de tamanho médio, peso médio de $140 \mathrm{~g}$, cerca de 20 sementes por fruto, formato achatado, com uma pequena cavidade no seu eixo central. Sua casca é de cor laranja vivo, com espessura fina, aderente e com vesículas de óleo em nível; a polpa é de cor laranja vivo e sua textura é firme; seu suco é abundante, representando cerca de $48 \%$ do peso do fruto, com teor de sólidos solúveis de $12,6^{\circ}$ Brix e $0,92 \%$ de acidez titulável (Davies \& Albrigo, 1994 e Figueiredo, 1991).

O fruto típico do citros é o hesperídeo, com casca formada por duas partes distintas, o albedo e o flavedo. O albedo é a parte mais espessa do mesocarpo, de cor branca e o flavedo é a parte mais externa, rica em glândulas de óleos essenciais. Internamente o fruto é dividido em diversos segmentos chamados comumente de gomos. Os segmentos revestidos por finas paredes membranosas contêm as vesículas de suco e as sementes. O suco das 
vesículas contém açúcares, ácidos orgânicos, sais minerais, enzimas, carotenos e licopenos (Koller, 1994).

O tangor 'Murcott' possui ótima aceitação no mercado para o consumo in natura, porém sua casca é relativamente fina e bastante aderida ao fruto, o que dificulta seu descascamento, tendo, assim, um grande potencial de ser comercializado sob a forma de produto minimamente processado.

As variedades comerciais de tangerina mais cultivadas no país são as tangerinas 'Poncã”, 'Murcott', 'Cravo' e 'Mexerica', que são responsáveis por cerca de $62 \%, 20 \%, 11 \%$ e $8 \%$, respectivamente, da produção de frutos no grupo das tangerineiras (Figueiredo, 1991; Camargo et al., 2002).

A produção brasileira de 'Murcott' é destinada aos mercados interno e externo para o consumo in natura (Figueiredo, 1991). Entre os anos de 1998 e 2001 houve um aumento de cerca de 18\% do volume de 'Murcott' comercializado no Ceagesp - SP, e no mesmo período verificou-se queda de $18,75 \%$ no preço deste produto (FNP, 2003).

A 'Murcott' é uma variedade de maturação tardia. O pico de sua produção, no Brasil, se dá entre os meses de agosto a novembro (Figueiredo, 1991), sendo uma das últimas tangerinas a entrar no mercado. Apesar de não ser a tangerina preferida no mercado brasileiro, sua qualidade interna está entre uma das melhores entre as tangerinas ou seus híbridos. Sua casca e suco adquirem coloração alaranjada intensa no seu ponto ótimo de maturação, sendo bastante atrativa (Davies \& Albrigo, 1994).

\subsection{Processamento mínimo}

Produtos minimamente processados são vegetais frescos, higienizados, submetidos a uma ou mais alterações físicas (descascamento, corte, fatiamento, etc.), prontos para o consumo ou preparo.

Nos últimos anos tem sido enfatizada a necessidade de consumo de frutas e hortaliças frescas, buscando-se uma dieta mais saudável. Ao mesmo 
tempo há uma demanda crescente por alimentos convenientes, frescos, menos processados e prontos para o consumo. A indústria de alimentos tem respondido a esta demanda com o desenvolvimento dos produtos hortícolas minimamente processados. Esta técnica visa satisfazer a necessidade do consumo de frutas e hortaliças frescas, saudáveis e com qualidade nutricional e sensorial.

Frutas e hortaliças minimamente processadas são, geralmente, mais perecíveis do que quando intactas, devido aos severos estresses físicos a que são submetidas, advindos principalmente das operações de descascamento e corte. Estes danos aumentam o metabolismo dos produtos, causando o aumento da respiração e, em alguns casos, aumentando a produção de etileno (Rosen \& Kader, 1989). O corte e a manipulação dos tecidos durante o processamento também são responsáveis pelo aumento da contaminação desses produtos por microorganismos patogênicos e deterioradores. $O$ aumento no metabolismo e na contaminação por microorganismos é responsável por uma deterioração mais rápida do vegetal.

Devido à alta perecibilidade destes produtos, os inúmeros fatores que afetam sua qualidade, tais como: temperatura, umidade relativa, atmosfera modificada, aspectos fisiológicos, bioquímicos e microbiológicos devem ser observados para garantir sua qualidade e sanidade.

\subsection{Fatores que influenciam a qualidade de produtos minimamente processados}

\subsubsection{Temperatura}

O controle da temperatura é a técnica mais útil para minimizar os efeitos da injúria causada nas frutas e hortaliças minimamente processadas, pois a velocidade das reações metabólicas é reduzida em duas a três vezes a cada $10^{\circ} \mathrm{C}$ de abaixamento na temperatura. Desta forma, o aumento da respiração e da taxa de produção de etileno associadas à injúria dos tecidos são 
minimizados com a manutenção dos produtos minimamente processados sob baixas temperaturas (Brecht, 1995).

As baixas temperaturas em todas as fases desde o processamento até 0 consumo é o fator mais importante para a manutenção da qualidade dos produtos minimamente processados. A alta umidade relativa encontrada no interior das embalagens dos produtos minimamente processados favorece a proliferação de fungos e bactérias, o que reforça a necessidade de refrigeração para uma melhor conservação dos mesmos (Luengo \& Lana, 1997).

Frutas e hortaliças minimamente processadas não sofrem tratamento térmico e devem ser manuseadas e armazenadas sob baixas temperaturas para garantir uma vida de prateleira conveniente e garantir segurança microbiológica. Porém, alguns patógenos como, Listeria monocytogenes, Yersinia enterocolitica, Salmonella spp. e Aeromonas hydrophyla podem sobreviver e até se proliferar em baixas temperaturas. Entretanto, as frutas minimamente processadas podem ser consideradas seguras, pois são ácidas o suficiente para prevenir o crescimento de alguns patógenos, sendo que sua microbiota predominante é constituída por fungos filamentosos e leveduras fracamente fermantativas (Ahvenainen, 1996).

Watada et al. (1996), ao compararem a taxa respiratória de vários frutos intactos e submetidos ao processamento mínimo, sob diversas temperaturas, observaram que na maioria das vezes a taxa respiratória era maior nos frutos minimamente processados e que quanto maior a temperatura, maior era a taxa respiratória.

Laranjas descascadas armazenadas a $4^{\circ} \mathrm{C}$ podem ser conservadas por 17 dias, porém se armazenadas a $21^{\circ} \mathrm{C}$ podem ser conservadas por apenas um dia (Pao \& Petracek, 1997). Vitti et al. (2002) estudaram o efeito da temperatura de armazenamento na conservação de tangor 'Murcott' minimamente processado, observaram que estes podem ser conservados por 9 dias a $2^{\circ} \mathrm{C} \mathrm{e}$ 3 dias quando armazenados a $6^{\circ}$ ou $12^{\circ} \mathrm{C}$. 
Aproximadamente $40 \%$ dos produtos minimamente processados disponíveis no mercado são sensíveis ao dano por frio, porém, o dano só é causado quando o produto é exposto a uma temperatura abaixo da temperatura mínima de segurança por um longo período de tempo. Como esses produtos são expostos apenas por um curto período e são altamente perecíveis quando comparados aos vegetais intactos, uma temperatura que pode causar um pequeno dano por frio é preferida àquela que causa uma deterioração mais rápida. As frutas utilizadas para o processamento mínimo devem estar no ponto ideal de maturação, e frutas maduras são menos sensíveis aos danos por frio que as frutas verdes. A temperatura ótima para armazenamento depende da vida útil estimada e do produto, pois espécies e cultivares diferem quanto à sensibilidade ao frio (Watada \& Qi, 1999).

\subsubsection{Umidade relativa}

A perda de água é uma das principais causas de deterioração de frutas e hortaliças após a colheita, e uma vez que os produtos minimamente processados possuem uma relação superfície/volume superior aos vegetais intactos, a perda de água e suas conseqüências são mais acentuada.

A maioria das frutas e hortaliças é composta por 80 a $95 \%$ de água. $A$ umidade relativa dos espaços intercelulares é muito próxima de 100\%, e freqüentemente $\mathrm{o}$ ambiente possui umidade relativa inferior a este valor, fazendo com que o vapor d'água se difunda destes espaços para o ambiente, através do processo de transpiração.

A perda de água é responsável pela perda de turgidez e pelo enrugamento dos tecidos vegetais, o que pode causar a rejeição do produto pelos consumidores. Em alguns produtos é necessário realizar uma centrifugação para remover o excesso de água da superfície e, assim, reduzir o crescimento microbiano. A operação de centrifugação é recomendada apenas para algumas hortaliças. Em frutas, devido ao elevado teor de suco e à 
fragilidade da polpa, esta operação é realizada com escorredores para garantir uma drenagem adequada.

\subsubsection{Atmosfera modificada}

A conservação dos vegetais em condições de atmosfera modificada pode ser definida como o armazenamento sob condição atmosférica diferente daquela presente na atmosfera do ar normal. Na atmosfera normal são encontradas concentrações de cerca de $0,03 \%$ de $\mathrm{CO}_{2}$ e de $21 \%$ de $\mathrm{O}_{2}$. $\mathrm{O}$ princípio básico da conservação em atmosfera modificada consiste na redução da taxa respiratória e de outros processos metabólicos responsáveis pela deterioração dos produtos, através da alteração da composição gasosa no interior da embalagem.

O sistema com atmosfera modificada mais utilizado consiste no acondicionamento do produto minimamente processado em uma embalagem selada e semipermeável a gases, a fim de reduzir a concentração de $\mathrm{O}_{2} \mathrm{e}$ aumentar a concentração de $\mathrm{CO}_{2}$ no interior da mesma. A magnitude das alterações nas concentrações destes compostos depende da natureza e da espessura do material de embalagem, da taxa respiratória do produto, da relação entre a área de permeação da embalagem e a massa produto e da temperatura de armazenamento.

Arruda (2002) afirma que o melão rendilhado cultivar 'Bonus II' minimamente processado apresenta vida útil de seis dias quando acondicionado em embalagem sem atmosfera modificada e vida útil de 12 dias quando acondicionado em filme poliolefínico ou de polipropileno com $20 \%$ de $\mathrm{CO}_{2}$ e $5 \%$ de $\mathrm{O}_{2}$ quando armazenado a $3^{\circ} \mathrm{C}$.

A atmosfera modificada pode ser realizada também através da utilização de recobrimentos comestíveis, os quais promovem barreira semipermeável aos gases e ao vapor d'água. Desta forma, reduzem a taxa respiratória e a perda de água, garantindo aumento da vida de prateleira dos vegetais. A utilização de 
ceras microemulsionadas como recobrimentos comestíveis em gomos de grapefruit reduziram significativamente a perda de água após o processamento (Baker \& Hagenmaier, 1997).

A atmosfera modificada apresenta efeitos diretos nos processos fisiológicos e bioquímicos do vegetal minimamente processado, bem como na redução da proliferação microbiana e desse modo aumenta a vida de prateleira dos vegetais.

\subsubsection{Aspectos fisiológicos e bioquímicos}

O corte dos tecidos realizado no preparo dos produtos minimamente processados estimula o aparecimento de mudanças fisiológicas indesejáveis. A integridade celular é perdida, destruindo a compartimentalização de enzimas e substratos, tendo como conseqüência a formação de metabólitos secundários. A senescência pode ser acelerada e odores indesejáveis podem ser desenvolvidos, como resultados do aumento da respiração e da produção de etileno (Burns, 1995).

A injúria causada aos tecidos durante o processamento mínimo causa uma elevação na biossíntese de etileno, que por sua vez, aumenta a taxa respiratória dos tecidos vegetais.

A taxa respiratória de um produto é um bom indicativo do seu tempo de conservação, sendo que a perecibilidade de um produto é diretamente proporcional à sua atividade respiratória.

Sob o ponto de vista bioquímico, as modificações no aroma e no sabor dos produtos minimamente processados são decorrentes da peroxidação enzimática de ácidos graxos insaturados, que é catalizada pela lipoxigenase, levando à formação de aldeídos e cetonas (Hildebrand, 1989). 


\subsubsection{Aspectos microbiológicos}

O processamento mínimo favorece a contaminação de alimentos por microrganismos deterioradores e patogênicos, em razão do manuseio e do aumento das injúrias nos tecidos (Wiley, 1994). Diversos microrganismos têm sido encontrados em produtos minimamente processados, incluindo bolores, leveduras, coliformes, microbiotas mesofílicas e pectnolíticas, entre outros (Nguyen-the \& Carlin, 1994). Os microrganismos encontrados em frutos diferem daqueles encontrados em hortaliças. Os fungos são os microrganismos predominantes nas frutas, devido ao baixo $\mathrm{pH}$ que estas apresentam (Wiley, 1994).

A contagem de microrganismos mesófilos aeróbios permite avaliar as condições microbiológicas de processamento de alimento. Números elevados normalmente diminuem seu tempo de vida útil (Hajdenwurcel, 1998). Segundo Hiraushi \& Horie (1982), os coliformes são bons indicadores de contaminação fecal em alimentos. De acordo com a "International Commission on Microbiological Specifications for Foods - ICMSF"(1978), a presença de coliformes em alimentos indica manipulação inadequada durante 0 processamento, uso de equipamentos em más condições sanitárias ou ainda utilização de matéria-prima contaminada.

A sanitização dos produtos minimamente processados é extremamente importante, uma vez que a refrigeração é utilizada para manter a qualidade dos produtos e esta não provém uma adequada proteção contra microorganismos patogênicos. Porém várias bactérias patogênicas sobrevivem e até mesmo se reproduzem em condições refrigeradas (Hurst, 1995).

Dessa forma, torna-se importante a sanitização de toda a planta de processamento, inclusive dos instrumentos e equipamentos, a utilização de luvas, máscaras, aventais e botas por parte dos operadores, bem como o uso de água clorada para a lavagem dos vegetais e utilização de matéria-prima de qualidade. 


\subsection{Recobrimentos comestíveis}

A utilização de recobrimentos comestíveis é uma das formas de criar uma barreira semipermeável a gases e vapor d'água, reduzindo, assim, a taxa respiratória e a perda de água e garantindo o aumento da vida de prateleira de produtos minimamente processados (Baldwin et al., 1995b). A utilização de ceras microemulsionadas como recobrimentos comestíveis em gomos de grapefruit reduziu a perda de água em 93\% uma semana após o processamento e, em $64 \%$ quatro semanas após o processamento (Baker \& Hagenmaier, 1997).

A utilização de coberturas à base de gelatina, triacetina e ácido láurico foram eficientes no controle do amadurecimento de goiabas, aumentando sua vida útil em 8 dias. Além disso, a utilização destas coberturas provocou um aumento no brilho das frutas, levando a uma maior aceitação do produto (Fakhouri \& Grosso, 2003).

Os materiais mais utilizados na composição de recobrimentos comestíveis são os lipídios (óleo ou cera de parafina, cera de abelhas, cera de carnaúba, óleo vegetal, óleo mineral, etc.), polissacarídeos (celulose, pectina, amido, carragena, etc.) e proteínas (caseína, gelatina, albumina de ovo, etc.) (Baldwin et al., 1995a).

A gelatina é uma proteína obtida a partir da hidrólise do colágeno. $O$ processo envolve tratamentos ácido e alcalino, seguidos de tratamento de calor na presença de água (Gennadios et al., 1994). A gelatina pode ser extraída de diversos materiais frescos como couro suíno e couro e ossos bovinos (Yong, 1967), que necessitam de um preparo inicial para a obtenção da gelatina, como por exemplo, a retirada de gordura e a desmineralização de ossos.

A gelatina é conhecida por formar filmes claros, flexíveis, resistentes e impermeáveis ao oxigênio, quando preparada em solução aquosa com plastificante glicerina ou sorbitol (Gennadios et al., 1994). Os filmes à base de 
gelatina possuem grande permeabilidade ao vapor de água, por possuírem caráter hidrofílico.

As proteínas do soro do leite, quando processadas apropriadamente, produzem filmes flexíveis, transparentes e sem odores (Gennadios et al., 1994). Os filmes de proteínas do soro apresentam permeabilidade ao oxigênio quando armazenados em ambientes com alta umidade relativa (Cisneros-Zevallos \& Krochta, 2002). A permeabilidade ao vapor de água destes filmes está mais relacionada com as concentrações de glicerol e de íon cálcio do que com a concentração de proteínas (Fang et al., 2002).

Coberturas à base de proteínas do soro do leite formam excelentes barreiras ao $\mathrm{O}_{2}$, devido à natureza polar de suas proteínas. $\mathrm{O}$ aumento da umidade relativa aumenta exponencialmente a permeabilidade ao $\mathrm{O}_{2}$ (Chen, 1995).

A cera de parafina é derivada da cera da fração destilada do petróleo cru. É composta por frações de hidrocarbonetos de fórmula genérica $C_{n} H_{2 n+2}$, variando de 18 a 32 unidades de carbono. A cera sintética de parafina tem seu uso permitido em alimentos nos Estados Unidos. Ceras de parafina podem ser utilizadas como recobrimentos em frutas e vegetais crus e em queijos.

Os recobrimentos à base de lipídeos são pouco permeáveis a vapor d'água e gases, sendo que, no armazenamento em altas temperaturas podem ser criadas condições anaeróbicas (Baldwin et al., 1995a). Já os recobrimentos a base de polissacarídeos têm como vantagens sua baixa permeabilidade a gases e sua aderência a superfície hidrofílicas, não sendo uma boa barreira a umidade (Baldwin et al., 1995b). As proteínas formam filmes que podem ser utilizados como recobrimentos comestíveis, promovendo uma boa barreira a $\mathrm{O}_{2}$ e $\mathrm{CO}_{2}$, não sendo, porém uma boa barreira à umidade (Baldwin et al., 1995b).

Oliveira (1996) ao estudar a possibilidade de substituição de ceras comerciais à base de lipídios por recobrimentos à base de fécula de mandioca, verificou que a substituição é viável e que há redução na taxa respiratória e na 
perda de massa de goiaba recobertas com película de fécula de mandioca, em relação aos frutos testemunha. 


\section{ATIVIDADE RESPIRATÓRIA E PRODUÇÃO DE ETILENO DE TANGOR 'MURCOTT' EM FUNÇÃO DO NÍVEL DE PROCESSAMENTO MÍNIMO E DA TEMPERATURA DE ARMAZENAMENTO}

\section{Resumo}

O presente trabalho teve como objetivos determinar o efeito do nível de processamento mínimo e da temperatura de armazenamento na fisiologia de tangor 'Murcott' minimamente processado. Os frutos foram submetidos a dois níveis de processamento: tangores inteiros sem casca e tangores em gomos. Frutos intactos foram utilizados como controle. O processamento foi realizado em sala climatizada a $15^{\circ} \mathrm{C}$. As amostras foram acondicionadas em jarros herméticos de vidro e armazenadas sob cinco temperaturas: $1^{\circ}, 6^{\circ}, 11^{\circ}, 21^{\circ} \mathrm{e}$ $31^{\circ} \mathrm{C}$. Foram determinadas a taxa respiratória e a produção de etileno a cada hora durante as 10 primeiras horas após o processamento e, posteriormente, a cada 24 horas por sete dias. Determinaram-se também os quocientes de temperatura $\left(\mathrm{Q}_{10}\right)$. Tanto o nível de processamento como a temperatura de armazenamento afetaram a taxa respiratória de tangores 'Murcott'. A taxa respiratória dos tangores em gomos foi maior que a dos tangores descascados, que por sua vez, foi maior que o dos frutos intactos, em todas as temperaturas estudadas. A taxa respiratória dos tangores logo após o processamento foi elevada com o aumento da temperatura. Para os tangores descascados os valores foram de $8,4 \mathrm{mLCO} 2 \cdot \mathrm{kg}^{-1} \cdot \mathrm{h}^{-1}$ quando armazenados a $1^{\circ} \mathrm{C}$ a 33,2 $\mathrm{mLCO} 2 \cdot \mathrm{kg}^{-1} \cdot \mathrm{h}^{-1}$ quando a $31^{\circ} \mathrm{C}$. O mesmo comportamento foi encontrado nos gomos, com taxa respiratória variando de $12,3 \mathrm{mLCO}_{2} \cdot \mathrm{kg}^{-1} \cdot \mathrm{h}^{-1}$ para as amostras 
a $1^{\circ} \mathrm{C}$, a $48,5 \mathrm{mLCO} 2 \cdot \mathrm{kg}^{-1} \cdot \mathrm{h}^{-1}$ para $31^{\circ} \mathrm{C}$. Os níveis de etileno encontrados foram baixos e pouco consistentes ao longo do armazenamento. Os valores de $Q_{10}$ encontrados variaram de 1,33 a 2,02 para frutos intactos, de 1,22 a 2,21 para frutos descascados e de 1,09 a 2,60 para os gomos.

Palavras-chave: Tangor 'Murcott', processamento mínimo, respiração, temperatura de armazenamento.

\section{RESPIRTORY ACTIVITY AND ETHYLENE PRODUCTION OF TANGOR 'MURCOTT' AS AFFECTED BY PROCESSING LEVEL AND STORAGE TEMPERATURE}

\section{Summary}

The objectives of this work were to determine the effect of minimally processing level and storage temperature in the physiology of minimally processed tangor 'Murcott'. The fruits were subjected to two levels of processing: peeled fruits and segments. Whole fruits were used as control. The samples were packed in hermetic glass jars and stored under 5 temperatures: $1^{\circ}, 6^{\circ} \mathrm{C}, 11^{\circ}, 21^{\circ}$ and $31^{\circ} \mathrm{C}$. The respiratory rate and the ethylene production were analyzed every hour for 10 hours and then, every day for 7 days. The temperature quotients were determined too. The processing level and the storage temperature affected the respiratory rate of tangor 'Murcott'. The segments respiration was higher than the peeled fruits, and this was higher than the whole fruits in all storage temperatures. The respiratory rate of the peeled fruits after processing was elevates with storage temperature increase. The same pattern was showed by the segments. The ethylene levels were low and inconstant during the study. The temperature quotients ranged from 1,33 to 2,02 for whole fruits, from 1,22 to 2,21 for peeled fruits and from 1,09 to 2,60 for the segments. 
Key-words: 'Murcott', fresh-cut, respiration, storage temperature.

\subsection{Introdução}

O processamento mínimo é definido como qualquer alteração física causada em frutos e hortaliças que mantém o estado fresco desses produtos. Inclui as operações de seleção, lavagem, corte, sanitização, centrifugação, embalagem, armazenamento e comercialização (IFPA, 1999; Moretti, 1999).

A injúria causada aos tecidos vegetais pelo corte ou descascamento é um dos maiores obstáculos para a conservação dos produtos minimamente processados, uma vez que o dano aos tecidos aumenta em muitas vezes a taxa respiratória desses produtos (Cantwell, 1992). A produção de etileno e a perda de água também são aumentadas em decorrência da injúria causada durante o processamento.

O processamento mínimo favorece a contaminação por microorganismos patogênicos e deterioradores devido à manipulação e injúrias causadas aos tecidos (Wiley, 1994). Por outro lado, frutas e hortaliças intactas possuem mecanismos de proteção contra a invasão microbiana, como a casca e a presença de cera na superfície. Assim, pode-se dizer que os produtos minimamente processados são mais perecíveis que os produtos hortícolas in natura.

A intensidade do dano e a temperatura de armazenamento são alguns dos fatores que influenciam a intensidade da resposta aos danos causados nos produtos minimamente processados.

Vários trabalhos na literatura relatam estudos referentes ao metabolismo de diversas frutas e hortaliças minimamente processadas. No entanto, pouco é contemplado sobre frutas cítricas minimamente processadas.

Desta forma, o objetivo deste estudo foi verificar o efeito da temperatura e do nível de processamento mínimo na taxa respiratória, produção de etileno e quocientes de temperatura $\left(Q_{10}\right)$ de tangor 'Murcott'. 


\subsection{Material e métodos}

Tangores 'Murcott' provenientes da região de Engenheiro Coelho - SP foram obtidos numa casa de embalagens desta região e levados para o Laboratório de Pós-Colheita do Departamento de Produção Vegetal da Esalq/USP, onde foram selecionados quanto à ausência de defeitos e danos mecânicos. Os frutos foram lavados com detergente neutro, sanitizados com cloro (200 mg. $\mathrm{L}^{-1}$ ) por 10 minutos e armazenados nas temperaturas de estudo por 12 horas.

Decorrido o tempo de armazenamento, os frutos foram submetidos a dois níveis de processamento mínimo: a) frutos inteiros sem a casca e b) frutos em gomos. Frutos intactos foram utilizados como controle (Figura 1).

Tanto o descascamento, quanto a separação dos gomos foram realizados manualmente. Para a separação dos gomos utilizou-se uma espátula para facilitar a separação inicial destes e evitar danos por esmagamento devido à pressão exercida pelas mãos dos processadores. O preparo das amostras foi realizado em sala climatizada $\left(15^{\circ} \mathrm{C}\right)$ e sanitizada, e os processadores estavam devidamente paramentados com máscara, touca, avental e luvas descartáveis próprios para processamento mínimo.

Os tratamentos consistiram de: tangores intactos (controle), inteiros sem a casca e em gomos armazenados sob as temperaturas de $1^{\circ}, 6^{\circ}, 11^{\circ}, 21^{\circ} \mathrm{e}$ $31^{\circ} \mathrm{C}$.

Foram utilizadas amostras de $200 \mathrm{~g}$ do produto minimamente processado, que foram acondicionadas em jarros herméticos de vidro, durante trinta minutos, e armazenados sob as temperaturas desejadas. Na tampa de cada frasco foi colocado um septo de silicone através do qual foram retiradas alíquotas de gás de $1 \mathrm{~mL}$, utilizando-se seringa especial.

Essas amostras foram injetadas em Cromatógrafo a Gás, marca Thermoffinigan, modelo Trace 2000 GC equipado com coluna Porapack $\mathrm{N}$ de 
$2 \mathrm{~m}$ de comprimento, metanador e detetor de ionização de chama (FID). O hidrogênio foi utilizado como gás de arraste a $40 \mathrm{~mL} \cdot \mathrm{min}^{-1}$. As temperaturas mantidas no aparelho foram de $100^{\circ} \mathrm{C}$ no injetor, $100^{\circ} \mathrm{C}$ para a coluna, $250^{\circ} \mathrm{C}$ no detetor e para, o caso do $\mathrm{CO}_{2}, 350^{\circ} \mathrm{C}$ no metanador. $\mathrm{O} \mathrm{CO}_{2}$ foi quantificado pela calibração com padrões de $2150 \mu \mathrm{L} . \mathrm{L}^{-1}$ e $29900 \mu \mathrm{L} . \mathrm{L}^{-1}$ de $\mathrm{CO}_{2}$. Para a determinação dos teores de etileno a temperatura da coluna, injetor e detetor foram de $100^{\circ} \mathrm{C}, 100^{\circ} \mathrm{C}$ e $250^{\circ} \mathrm{C}$, respectivamente. $\mathrm{O}_{2} \mathrm{H}_{4}$ foi quantificado pela calibração com o padrão de $1,94 \mu \mathrm{L} . \mathrm{L}^{-1} \mathrm{C}_{2} \mathrm{H}_{4}$.

Para o cálculo da respiração e etileno foram levados em consideração o volume do frasco, a massa dos frutos e o tempo de acúmulo de $\mathrm{CO}_{2}$ e de $\mathrm{C}_{2} \mathrm{H}_{4}$. A taxa respiratória foi expressa em $\mathrm{mL} \mathrm{CO} \cdot \mathrm{Kg}^{-1} \cdot \mathrm{h}^{-1}$ e a de etileno em $\mu \mathrm{L} \mathrm{C} \mathrm{C}_{4}$ $\mathrm{Kg}^{-1} \cdot \mathrm{h}^{-1}$.

As determinações foram realizadas a cada hora durante as 10 primeiras horas após o processamento e, posteriormente, a cada 24 horas por mais sete dias.

Os quocientes de temperatura $\left(Q_{10}\right)$ foram calculados com base nas taxas de produção de $\mathrm{CO}_{2}$ a $1^{\circ} \mathrm{C}$ e a $11^{\circ} \mathrm{C} ; 11^{\circ} \mathrm{C}$ e a $21^{\circ} \mathrm{C}$ e a $21^{\circ} \mathrm{C}$ e a $31^{\circ} \mathrm{C}$, de acordo com a seguinte fórmula:

$$
Q_{10}=\frac{R\left(T+10^{\circ} \mathrm{C}\right)}{R\left(T^{\circ} \mathrm{C}\right)}
$$

onde:

$\mathrm{R}\left(\mathrm{T}^{\circ} \mathrm{C}\right)=$ taxa respiratória a temperatura $\mathrm{T}^{\circ} \mathrm{C}$.

$\mathrm{R}\left(\mathrm{T}+10^{\circ} \mathrm{C}\right)=$ taxa respiratória a temperatura $\mathrm{T}+10^{\circ} \mathrm{C}$

O delineamento experimental utilizado foi inteiramente casualizado em esquema fatorial triplo (níveis de processamento, temperaturas de armazenamento e épocas de avaliação), com 6 repetições por tratamento. Os resultados foram submetidos à análise do erro padrão. As diferenças entre dois 
tratamentos maiores que a soma de dois erros padrões foram consideradas significativas $(p \leq 0,05)$.

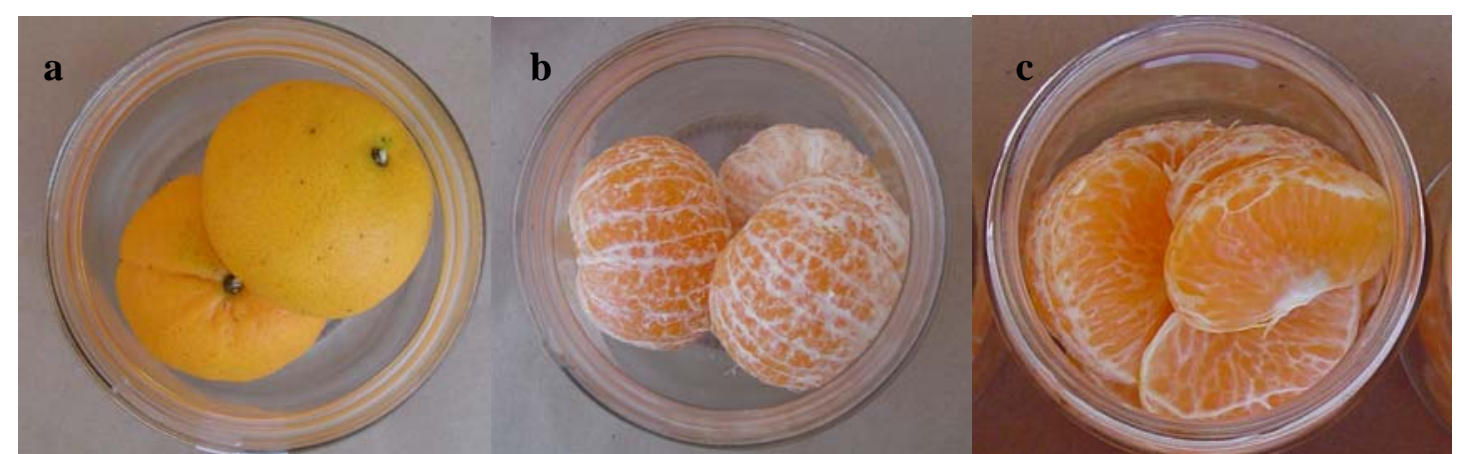

Figura 1 - Caracterização dos níveis de processamento mínimo: frutos intactos (a); frutos descascados (b); gomos (c)

\subsection{Resultados e discussão}

\subsubsection{Atividade respiratória em função da temperatura de armazenamento}

O aumento da temperatura de armazenamento causou elevação significativa na taxa respiratória dos frutos nos três níveis de processamento, para todos as faixas de temperatura utilizadas.

Frutos inteiros armazenados a $1^{\circ}, 6^{\circ}$ e $11^{\circ} \mathrm{C}$ apresentaram taxa respiratória praticamente estável durante todo o período de armazenamento, atingindo valores ao redor de $3,5 \mathrm{mLCO} \cdot \mathrm{kg}^{-1} \cdot \mathrm{h}^{-1}, 4,5 \mathrm{mLCO} 2 \cdot \mathrm{kg}^{-1} \cdot \mathrm{h}^{-1}$ e 7 $\mathrm{mLCO} 2 \cdot \mathrm{kg}^{-1} \cdot \mathrm{h}^{-1}$, respectivamente. Os frutos armazenados a $21^{\circ}$ e $31^{\circ} \mathrm{C}$ mantiveram a taxa respiratória constante e em torno de 16,5 e 27,5 $\mathrm{mLCO} \cdot \mathrm{kg}^{-1} \cdot \mathrm{h}^{-1}$, respectivamente, até a $10^{\mathrm{a}}$ hora de armazenamento, ocorrendo diminuição após este período. A taxa respiratória ao final do período de análise foi de $11,3 \mathrm{mLCO} 2 \cdot \mathrm{kg}^{-1} \cdot \mathrm{h}^{-1}$ para os frutos a $21^{\circ} \mathrm{C}$ e de $16,3 \mathrm{mLCO} \cdot \mathrm{kg}^{-1} \cdot \mathrm{h}^{-1}$ para os frutos a $31^{\circ} \mathrm{C}$ (Figura 2).

A taxa respiratória aumenta com 0 aumento da temperatura, principalmente na faixa de temperatura de $5^{\circ}$ a $20^{\circ} \mathrm{C}$. O uso de temperaturas 
mais elevadas pode suprimir a atividade respiratória (Chitarra \& Chitarra, 1990). A temperatura ótima recomendada para o armazenamento de tangerinas é de $5^{\circ}$ a $8^{\circ} \mathrm{C}$ (Arpaia \& Kader, 1999). Isto pode justificar a redução da taxa respiratória quando os frutos foram armazenados a $21^{\circ}$ e $31^{\circ} \mathrm{C}$.

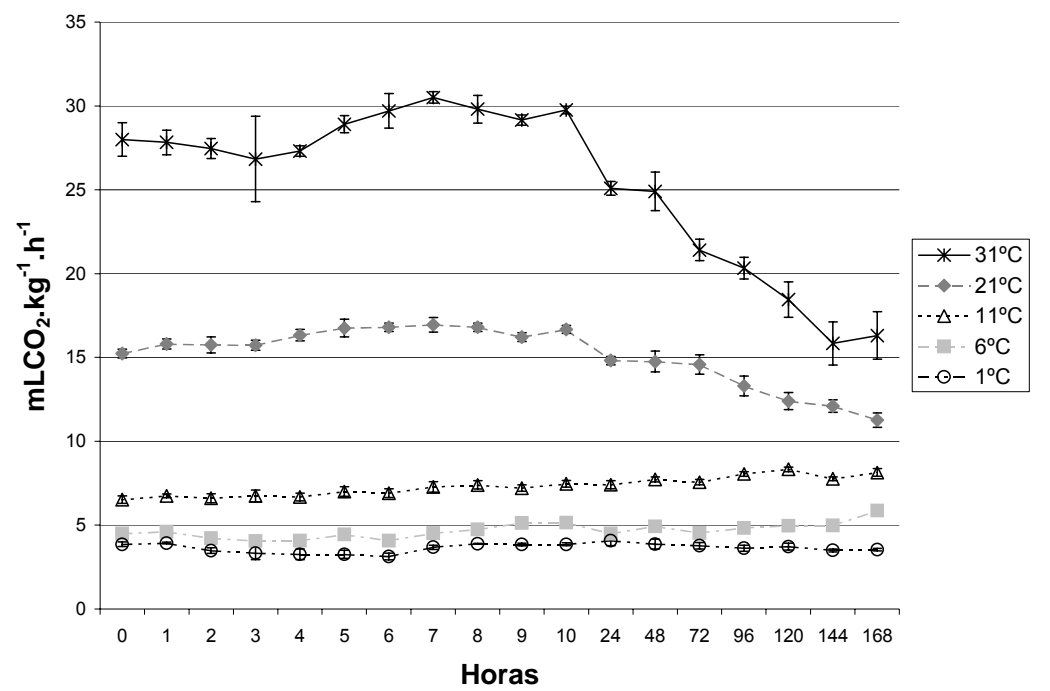

Figura 2 - Taxa respiratória de tangores 'Murcott' inteiros em função da temperatura de armazenamento. Barras verticais representam erro padrão da média

Os frutos inteiros descascados apresentaram a maior atividade respiratória imediatamente após o processamento. Este aumento na taxa respiratória pode ser explicado devido às injúrias sofridas pelos frutos durante o processamento mínimo, que causam a descompartimentação das células vegetais, permitindo que substratos e enzimas entrem em contato, causando uma deterioração mais rápida dos tecidos (Varoquaux \& Wiley, 1994). Quando armazenados a $1^{\circ} \mathrm{C}$ a taxa respiratória destes frutos atingiu valores de 8,36 $\mathrm{mLCO}_{2} \cdot \mathrm{kg}^{-1} \cdot \mathrm{h}^{-1}$; quando a $6^{\circ} \mathrm{C}$, de $9,30 \mathrm{mLCO} 2 \cdot \mathrm{kg}^{-1} \cdot \mathrm{h}^{-1}$; quando a $11^{\circ} \mathrm{C}$, de $10,20 \mathrm{mLCO} 2 \cdot \mathrm{kg}^{-1} \cdot \mathrm{h}^{-1}$; quando a $21^{\circ} \mathrm{C}$, de $20,41 \mathrm{mLCO} 2 \cdot \mathrm{kg}^{-1} \cdot \mathrm{h}^{-1}$ e quando a $31^{\circ} \mathrm{C}$, de $33,24 \mathrm{mLCO} \cdot \mathrm{kg}^{-1} \cdot \mathrm{h}^{-1}$. Uma hora após o armazenamento, houve 
estabilização da taxa respiratória para os frutos minimamente processados armazenados a $1^{\circ}, 6^{\circ}, 11^{\circ}$ e $21^{\circ} \mathrm{C}$, mantendo-se esta estável até o fim do período de estudo e em torno de $3,7 \mathrm{mLCO} 2 \cdot \mathrm{kg}^{-1} \cdot \mathrm{h}^{-1}, 4,4 \mathrm{mLCO}_{2} \cdot \mathrm{kg}^{-1} \cdot \mathrm{h}^{-1}, 6,5$ $\mathrm{mLCO}_{2} \cdot \mathrm{kg}^{-1} \cdot \mathrm{h}^{-1}$ e $14 \mathrm{mLCO} 2 \cdot \mathrm{kg}^{-1} \cdot \mathrm{h}^{-1}$, respectivamente (Figura 3). Porém, para os frutos armazenados a $21^{\circ} \mathrm{C}$, a partir da $96^{\mathrm{a}}$ hora de armazenamento ( $4^{\circ} \mathrm{dia}$ ), houve aumento da taxa respiratória, devido, provavelmente, à presença de Penicillium que houve nestas amostras (Figuras 3 e 5). Duas horas após o processamento houve estabilização da taxa respiratória das amostras armazenadas a $31^{\circ} \mathrm{C}$, este comportamento se manteve apenas até a $10^{\mathrm{a}}$ hora de armazenamento, com valores próximos a $25 \mathrm{mLCO} \cdot \mathrm{kg}^{-1} \cdot \mathrm{h}^{-1}$, havendo, a partir de então, uma tendência de queda até a o $2^{\circ}$ dia do estudo (48 horas), provavelmente devido à alta temperatura de armazenamento. A partir da 96 hora ( $\left.4^{\circ} \mathrm{dia}\right)$, houve tendência de aumento na taxa respiratória, o que se deveu, provavelmente, à presença de fungos do gênero Penicillium nas amostras armazenadas a $31^{\circ} \mathrm{C}$ (Figuras 3 e 5). Os microorganismos presentes nos tecidos de produtos minimamente processados são responsáveis pela produção de enzimas degradativas. No caso de fungos, são produzidas celulases e enzimas pectinolíticas, que causam a degradação dos tecidos, aumentando sua taxa respiratória e reduzindo sua vida útil (King \& Bolin, 1989). 


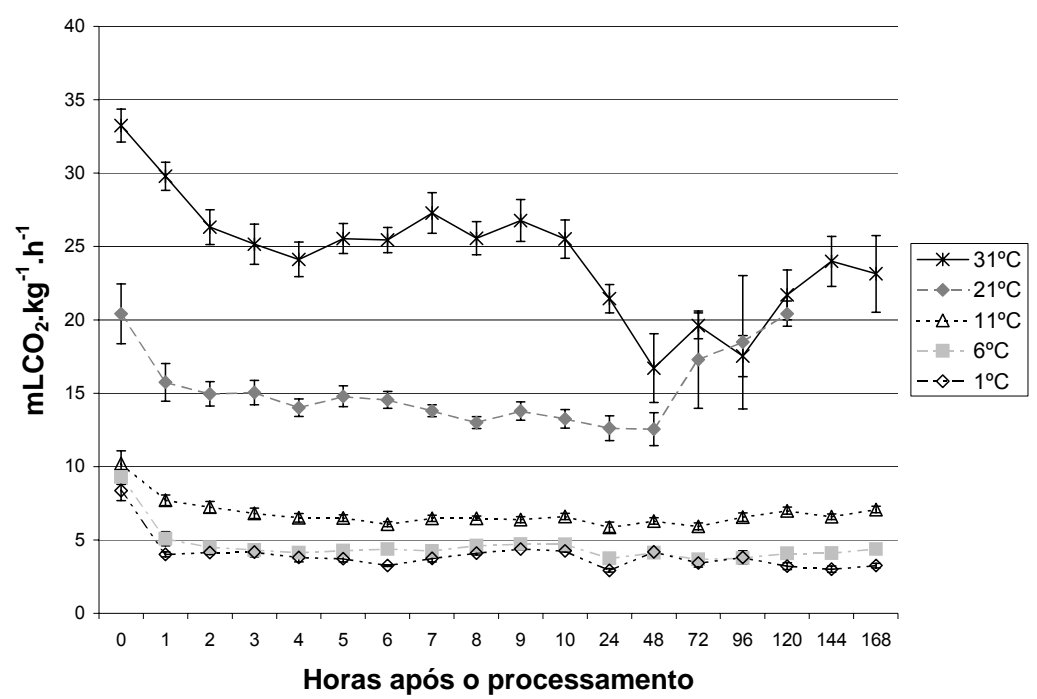

Figura 3 - Taxa respiratória de tangores 'Murcott' inteiros descascados em função da temperatura de armazenamento. Barras verticais representam erro padrão da média

Donadon et al. (2004), estudaram o efeito da temperatura sobre a taxa respiratória de tangores 'Murcott' intactos e minimamente processados. A respiração das frutas inteiras variou de $0,84 \mathrm{mLCO}_{2} \cdot \mathrm{kg}^{-1} \cdot \mathrm{h}^{-1}$ quando armazenadas a $5^{\circ} \mathrm{C}$ a $8,76 \mathrm{mLCO}_{2} \cdot \mathrm{kg}^{-1} \cdot \mathrm{h}^{-1}$ quando em temperatura ambiente $\left(21\right.$ a $23^{\circ} \mathrm{C}$ ). Os tangores descascados manualmente apresentaram pico na atividade respiratória, uma hora após o processamento $\left(5^{\circ} \mathrm{C}=11,83\right.$ $\mathrm{mLCO} 2 \cdot \mathrm{kg}^{-1} \cdot \mathrm{h}^{-1} ;$ ambiente $\left.=24,29 \mathrm{mLCO} \cdot \mathrm{kg}^{-1} \cdot \mathrm{h}^{-1}\right)$, seguido de queda $\mathrm{e}$ estabilização após nove horas $\left(5^{\circ} \mathrm{C}=3,20 \mathrm{mLCO} \cdot \mathrm{kg}^{-1} \cdot \mathrm{h}^{-1}\right.$; ambiente $=5,79$ $\left.\mathrm{mLCO}_{2} \cdot \mathrm{kg}^{-1} \cdot \mathrm{h}^{-1}\right)$.

Os frutos minimamente processados na forma de gomos apresentaram a maior atividade respiratória logo após o processamento, provavelmente devido às injúrias causadas aos tecidos durante as operações de processamento. Quando armazenados a $1^{\circ} \mathrm{C}$ a taxa respiratória dos frutos minimamente processados, imediatamente após o processamento atingiu valores de 12,33 $\mathrm{mLCO}_{2} \cdot \mathrm{kg}^{-1} \cdot \mathrm{h}^{-1}$; a $6^{\circ} \mathrm{C}, 13,14 \mathrm{mLCO} 2 \cdot \mathrm{kg}^{-1} \cdot \mathrm{h}^{-1}$; a $1^{\circ} \mathrm{C}, 13,45 \mathrm{mLCO} 2 \cdot \mathrm{kg}^{-1} \cdot \mathrm{h}^{-1}$; a 
$21^{\circ} \mathrm{C}, 27,84 \mathrm{mLCO} 2 \cdot \mathrm{kg}^{-1} \cdot \mathrm{h}^{-1}$ e a $31^{\circ} \mathrm{C}, 48,54 \mathrm{mLCO} 2 \cdot \mathrm{kg}^{-1} \cdot \mathrm{h}^{-1}$. Decorrida uma hora de armazenamento, houve estabilização da taxa respiratória das amostras armazenadas a $1^{\circ}, 6^{\circ}$ e $11^{\circ} \mathrm{C}$, mantendo-se esta praticamente constante e em torno de $4,5 \mathrm{mLCO} 2 \cdot \mathrm{kg}^{-1} \cdot \mathrm{h}^{-1}, 6 \quad \mathrm{mLCO}_{2} \cdot \mathrm{kg}^{-1} \cdot \mathrm{h}^{-1}$ e $10 \quad \mathrm{mLCO}_{2} \cdot \mathrm{kg}^{-1} \cdot \mathrm{h}^{-1}$, respectivamente, até $\mathrm{o}$ último dia de armazenamento. As amostras armazenadas a $21^{\circ} \mathrm{e} 31^{\circ} \mathrm{C}$ apresentaram estabilização da taxa respiratória após a $2^{\mathrm{a}}$ hora de armazenamento, com valores em torno de 25 e $42 \mathrm{mLCO} \cdot \mathrm{kg}^{-1} \cdot \mathrm{h}^{-1}$, respectivamente, até a $24^{\mathrm{a}}$ hora $\left(1^{\circ} \mathrm{dia}\right)$ para $21^{\circ} \mathrm{C}$ e até a $72^{\mathrm{a}}$ hora $\left(3^{\circ} \mathrm{dia}\right)$ para $31^{\circ} \mathrm{C}$, havendo aumento da taxa respiratória a partir de então, que pode ser explicada pela presença de fungos do gênero Penicillium nestas amostras (Figuras 4 e 5).

A produção de etileno foi bastante baixa e inconstante durante 0 experimento. Para os tangores inteiros descascados, foram detectados níveis de $0,0010 \mu \mathrm{L} \mathrm{C}_{2} \mathrm{H}_{4} \mathrm{Kg}^{-1} \cdot \mathrm{h}^{-1}$ para as amostras armazenadas a $1^{\circ} \mathrm{C} ; 0,052 \mu \mathrm{L}$ $\mathrm{C}_{2} \mathrm{H}_{4} \mathrm{Kg}^{-1} \cdot \mathrm{h}^{-1}$ para $11^{\circ} \mathrm{C} ; 0,15 \mu \mathrm{L} \mathrm{C}_{2} \mathrm{H}_{4} \mathrm{Kg}^{-1} \cdot \mathrm{h}^{-1}$ para $21^{\circ} \mathrm{C}$ e $0,12 \mu \mathrm{L} \mathrm{C}_{2} \mathrm{H}_{4} \mathrm{Kg}^{-1} \cdot \mathrm{h}^{-1}$ para $31^{\circ} \mathrm{C}$. Para os tangores minimamente processados na forma de gomos, os valores encontrados foram de $0,0084 \mu \mathrm{L} \mathrm{C}_{2} \mathrm{H}_{4} \mathrm{Kg}^{-1} \cdot \mathrm{h}^{-1}$ para as amostras armazenadas a $1^{\circ} \mathrm{C} ; 0,062 \mu \mathrm{L} \mathrm{C}{ }_{2} \mathrm{H}_{4} \mathrm{Kg}^{-1} \cdot \mathrm{h}^{-1}$ para $11^{\circ} \mathrm{C} ; 1,2 \mu \mathrm{L} \mathrm{C}_{2} \mathrm{H}_{4} \mathrm{Kg}^{-1} \cdot \mathrm{h}^{-1}$ para $21^{\circ} \mathrm{C}$ e de $1,15 \mu \mathrm{L} \mathrm{C} \mathrm{H}_{4} \mathrm{Kg}^{-1} \cdot \mathrm{h}^{-1}$ para $31^{\circ} \mathrm{C}$ (Dados não apresentados). Os citros têm taxa de produção de etileno considerada baixa (menor que $0,1 \mu \mathrm{L} \mathrm{C}_{2} \mathrm{H}_{4} \mathrm{Kg}^{-}$ ${ }^{1} \cdot \mathrm{h}^{-1}$ a $20^{\circ} \mathrm{C}$ ) (Kader, 1992), desta forma, a detecção de etileno destes frutos é dificultada. Além disso, as baixas temperaturas utilizadas em alguns tratamentos reduzem ainda mais a produção deste hormônio vegetal pelos tecidos. Frutas cítricas possuem padrão de atividade respiratória não climatérico, desta forma, não são observadas mudanças relativas ao amadurecimento dos frutos após a colheita. O tratamento pós-colheita com liberadores de etileno em citros visa o desverdecimento da casca, desta forma, pode-se supor que a produção de etileno e sua ação são mais evidentes nas 
células do albedo e do flavedo dos frutos, sendo bastante difícil observar a produção de etileno em frutos cítricos descascados ou em gomos.

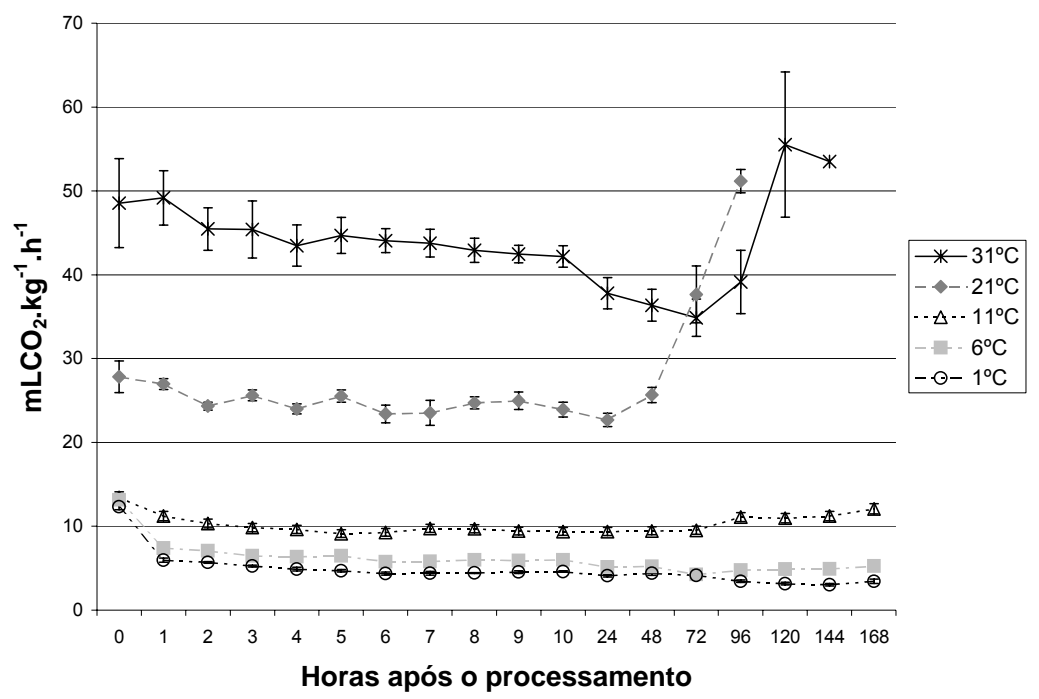

Figura 4 - Taxa respiratória de tangores 'Murcott' em gomos em função da temperatura de armazenamento. Barras verticais representam erro padrão da média

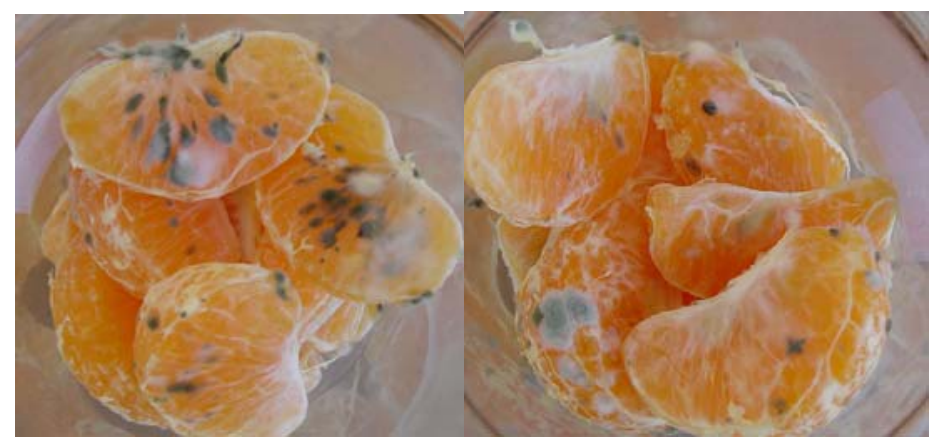

Figura 5 - Fungos do gênero Penicillium encontrados em algumas amostras

Devido à alta perecibilidade dos produtos minimamente processados, os fatores relacionados à qualidade destes produtos devem ser observados. De acordo com Watada et al. (1996), a temperatura, embalagem, umidade relativa e microrganismos são os principais fatores que afetam a qualidade dos produtos minimamente processados. 
O controle da temperatura é a técnica mais útil e importante para minimizar as injúrias provocadas pelo processamento mínimo de frutas e hortaliças. O aumento na respiração e na produção de etileno, bem como outras reações associadas ao processamento, são minimizados quando o produto é processado e mantido sob baixas temperaturas (Brecht, 1995).

$\mathrm{O}$ armazenamento dos produtos minimamente processados sob baixas temperaturas baseia-se no princípio de que estas reduzem o crescimento microbiano e são efetivas em reduzir a atividade enzimática (Wiley, 1994).

Watada et al. (1996), ao compararem a taxa respiratória de vários frutos intactos e submetidos ao processamento mínimo, sob diversas temperaturas, observaram que na maioria das vezes a taxa respiratória era maior nos frutos minimamente processados e que quanto maior a temperatura, maior era a taxa respiratória.

Vitti et al. (2002) estudaram o efeito da temperatura de armazenamento na conservação de tangor 'Murcott' minimamente processado e observaram que estes podem ser conservadas por 9 dias a $2^{\circ} \mathrm{C}$ e 3 dias quando armazenadas a $6^{\circ}$ ou $12^{\circ} \mathrm{C}$. Tangerinas 'Ponkan" minimamente processadas podem ser conservadas por até 6 dias a $6^{\circ} \mathrm{C}$, sem comprometimento de seus atributos de qualidade (Vilas Boas et al., 2000).

\subsubsection{Atividade respiratória em função do nível de processamento mínimo}

Os dois níveis de processamento mínimo utilizados causaram alteração significativa no metabolismo respiratório dos tangores 'Murcott' para todas as temperaturas estudadas. Quanto maior o nível de processamento mínimo, maior foi a atividade respiratória dos frutos imediatamente após 0 processamento (Figura 6).

$\mathrm{Na} 5^{\mathrm{a}}$ hora após o processamento, a taxa respiratória dos frutos descascados praticamente se igualou à dos frutos inteiros, porém, a respiração 
dos gomos se manteve superior que a dos demais níveis em todas as temperaturas estudadas (Figura 7).

A lesão dos tecidos de um vegetal causada pelas operações de processamento mínimo provoca a perda da compartimentação celular, o que ativa o sistema gerador de etileno, estimulando sua síntese. A elevação na respiração dos tecidos injuriados, decorrentes do processamento mínimo, é uma conseqüência do incremento na produção de etileno e da perda de compartimentação celular (Brecht, 1995).

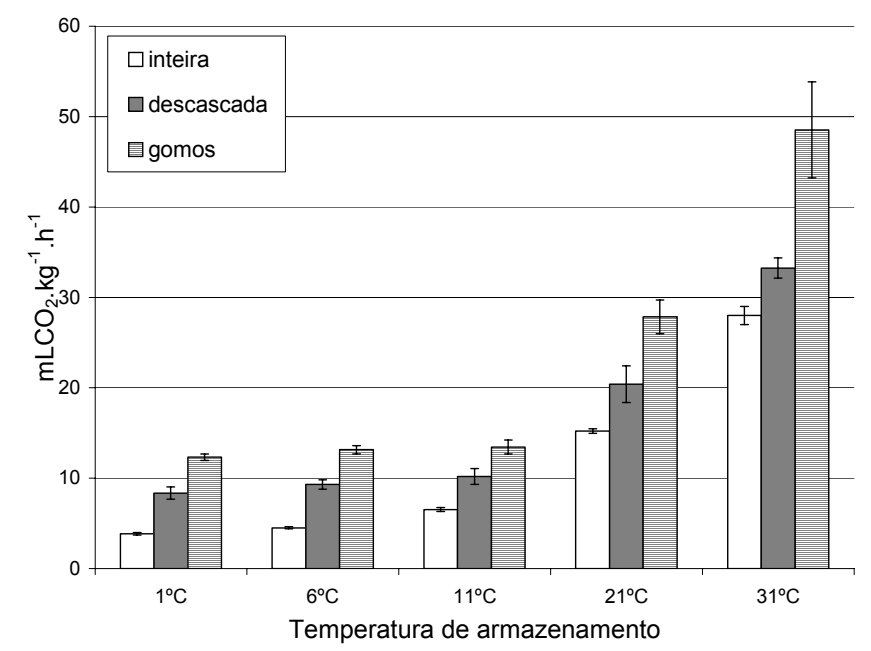

Figura 6 - Taxa respiratória de tangores 'Murcott' em função do nível de processamento mínimo imediatamente após o processamento. Barras verticais representam erro padrão da média 


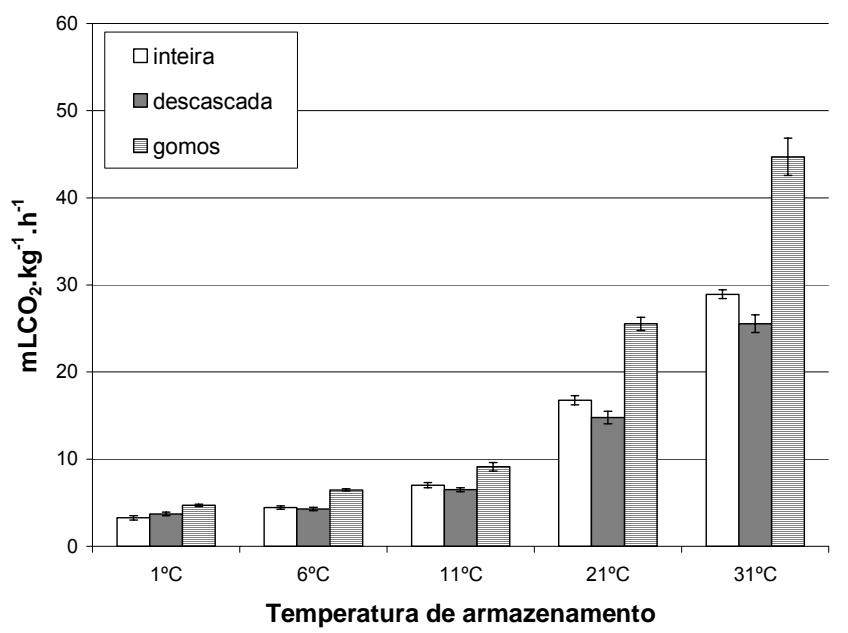

Figura 7 - Taxa respiratória de tangores 'Murcott' armazenados em função do nível de processamento mínimo na $5^{\mathrm{a}}$ hora após o processamento. Barras verticais representam erro padrão da média

\subsubsection{Quocientes de temperatura $\left(Q_{10}\right)$}

A faixa de temperatura utilizada durante o experimento permitiu também a obtenção dos valores de $Q_{10}$ para três conjuntos de temperaturas: $1^{\circ} \mathrm{e} 11^{\circ} \mathrm{C}$, $11^{\circ}$ e $21^{\circ} \mathrm{C}$, e $21^{\circ}$ e $31^{\circ} \mathrm{C}$.

Para frutos inteiros, os valores de $Q_{10}$ encontrados variaram de 1,69 a 2,02 para o conjunto $1^{\circ}$ e $11^{\circ} \mathrm{C}$, de 1,33 a 2,30 para o conjunto $11^{\circ}$ e $21^{\circ} \mathrm{C}$ e de 1,69 a 1,84 para $21^{\circ}$ e $31^{\circ} \mathrm{C}$ (Figura 8).

Para os frutos descascados, os valores de $Q_{10}$ encontrados oscilaram entre 1,22 a 2,00 para o intervalo $1^{\circ} \mathrm{e} 11^{\circ} \mathrm{C}$, entre 2,00 e 2,21 para $11^{\circ}$ e $21^{\circ} \mathrm{C}$ e entre 1,63 e 1,7 para $21^{\circ}$ e $31^{\circ} \mathrm{C}$ (Figura 9). 
Os tangores minimamente processados na forma de gomos apresentaram valores de $Q_{10}$ entre 1,09 e 2,28 para a faixa de temperatura entre $1^{\circ}$ e $11^{\circ} \mathrm{C}$, entre 2,07 e 2,60 para $11^{\circ}$ e $21^{\circ} \mathrm{C}$ e entre 1,67 e 1,77 para $21^{\circ}$ e $31^{\circ} \mathrm{C}$ (Figura 10$)$.

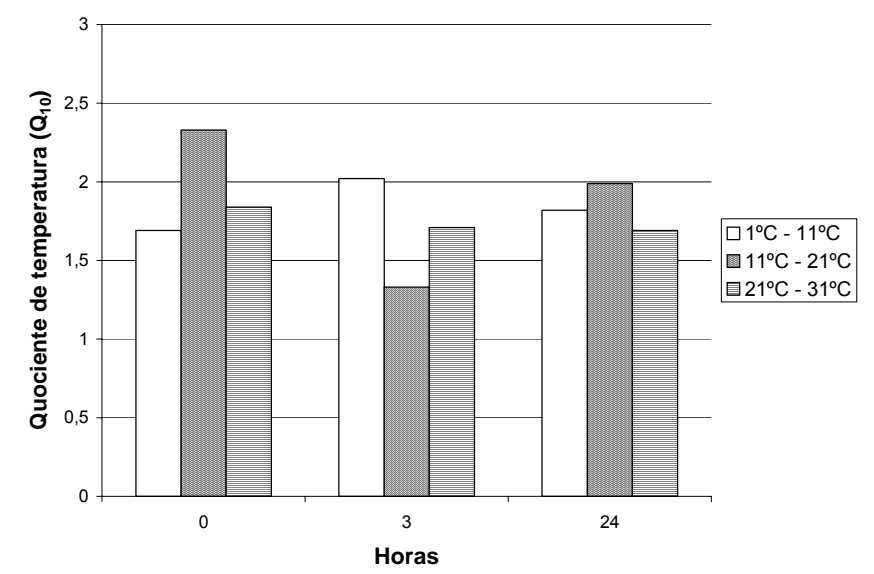

Figura 8 - Valores do quociente de temperatura $\left(Q_{10}\right)$ para tangores 'Murcott' intactos

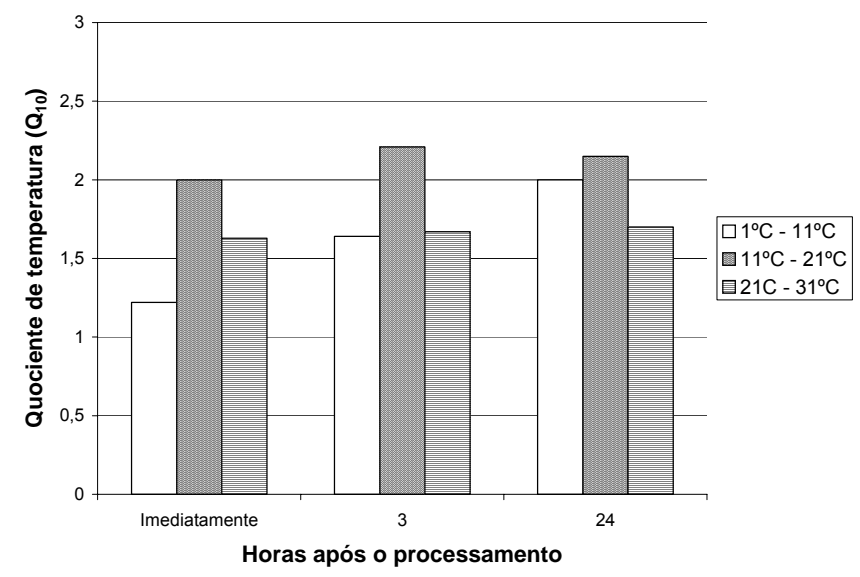

Figura 9 - Valores do quociente de temperatura $\left(Q_{10}\right)$ para tangores 'Murcott' descascados 


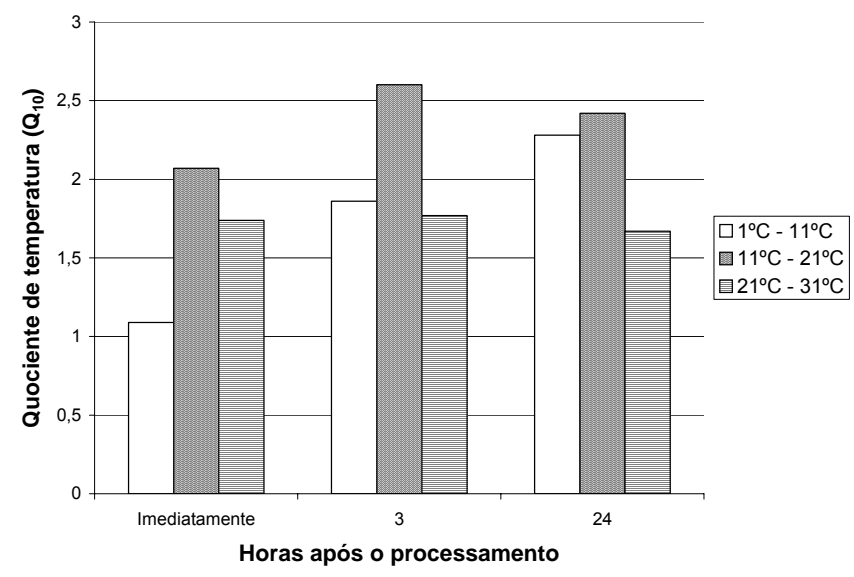

Figura 10 - Valores do quociente de temperatura $\left(Q_{10}\right)$ para gomos de tangor 'Murcott'

A maior parte das reações metabólicas dos vegetais são catalisadas por enzimas. A velocidade destas reações é reduzida em duas a três vezes a cada abaixamento de $10^{\circ} \mathrm{C}$ na temperatura (Brecht, 1995). Desta forma, a redução da temperatura diminui a taxa respiratória e a produção de etileno dos produtos minimamente processados.

Os valores de $Q_{10}$ encontrados para o conjunto de temperaturas $11^{\circ} \mathrm{e}$ $21^{\circ} \mathrm{C}$ foram, na maioria das vezes, maiores que os valores encontrados para os demais conjuntos. Assim, pode-se inferir que a retirada dos produtos minimamente processados das temperaturas de refrigeração e sua exposição à temperatura ambiente resulta num maior aumento das reações metabólicas do que quando apenas se aumenta a temperatura de refrigeração utilizada.

Apesar destes valores situarem-se abaixo dos valores de $Q_{10}$ para frutas minimamente processadas citados por Watada et al. (1996), que variam de 3 a 4 , estão próximos dos valores citados para algumas hortaliças minimamente processadas. 


\subsection{Conclusões}

Através dos resultados obtidos, pode-se concluir que:

* Tangores 'Murcott' minimamente processados apresentam menor taxa respiratória quando armazenados a $1^{\circ}$ ou $6^{\circ} \mathrm{C}$, independente do nível de processamento.

* O nível de processamento mínimo influencia a taxa respiratória de tangores 'Murcott', principalmente nas duas primeiras horas após o processamento, sendo a taxa respiratória dos frutos processados na forma de gomos sempre maior que a dos demais níveis.

* O aumento da temperatura de armazenamento em $10^{\circ} \mathrm{C}$ aumenta a taxa respiratória de tangor 'Murcott' minimamente processado em até 2,6 vezes.

* Os níveis de etileno em tangor 'Murcott' minimamente processados são baixos e inconstantes. 


\section{RECOBRIMENTOS COMESTÍVEIS PARA TANGOR 'MURCOTT' MINIMAMENTE PROCESSADO}

\section{Resumo}

O objetivo deste estudo foi avaliar a eficiência de recobrimentos comestíveis na redução da taxa respiratória e na manutenção da qualidade microbiológica, sensorial e físico-química de tangor 'Murcott' minimamente processado. Tangores 'Murcott' foram minimamente processados na forma de gomos, tratados com diversos recobrimentos comestíveis e armazenados a $6^{\circ} \mathrm{e}$ $12^{\circ} \mathrm{C}$. Os recobrimentos utilizados foram: gelatina a $4 \% \mathrm{p} / \mathrm{p}$, gelatina a $8 \% \mathrm{p} / \mathrm{p}$, concentrado protéico de soro de leite a $8 \%$ p/p e emulsão a base de parafina. Tangores sem recobrimentos foram utilizados como controle. Determinaram-se: as características físico-químicas a cada dois dias por um período de seis dias; a taxa respiratória diariamente por oito dias; as características microbiológicas no quarto e sétimo dias após o processamento e as características sensoriais no quarto dia após o processamento. Os recobrimentos comestíveis não foram efetivos na redução da atividade respiratória. De maneira geral, os teores de ácido ascórbico, a acidez titulável e a coloração não foram influenciados pelos recobrimentos comestíveis. Por outro lado, houve aumento da perda de massa quando os gomos foram recobertos com gelatina a $8 \%$. O recobrimento à base de concentrado protéico de soro de leite reduziu o desenvolvimento de bactérias psicrotróficas e anaeróbias e de bolores e leveduras. A emulsão à base de parafina aumentou a contagem de bactérias psicrotróficas e de bolores e leveduras. Coliformes totais e fecais e Salmonella não foram detectados nas amostras analisadas. Houve pouca influência dos recobrimentos comestíveis na 
manutenção das características sensoriais. De maneira geral, os recobrimentos foram pouco efetivos na manutenção das características fisiológicas, físicoquímicas, microbiológicas e sensoriais de tangor 'Murcott' minimamente processado.

Palavras-chave: Tangor 'Murcott', processamento mínimo, recobrimentos comestíveis

\section{EDIBLE COATINGS FOR FRESH-CUT TANGOR 'MURCOTT'}

\section{Summary}

The objective of this work was to evaluate the edible coatings efficiency on the respiratory rate reduction and on the maintenance of the microbiological, sensorial and physico-chemical qualities of fresh-cut tangor 'Murcott'. Tangor 'Murcott' separated in segments recovered with several edible coatings were stored under $6^{\circ}$ and $12^{\circ} \mathrm{C}$. The coatings were: gelatin $4 \%(\mathrm{w} / \mathrm{w})$, gelatin $8 \%$ $(\mathrm{w} / \mathrm{w})$, whey protein $8 \%(\mathrm{w} / \mathrm{w})$ and paraffin wax emulsion. Segments without recovering were used as control. The physico-chemical properties were determined every two day for six days; as well the respiratory rate daily for eight days; as well the microbiological analysis on the fourth and seventh days of storage; and the sensorial analysis were done on the fourth day of storage. The edible coatings were not effective on reducing the respiratory rate. In general, the ascorbic acid, the titratable acidity and the colour were not affected by the edible coatings. On the other hand, there was increasing in fresh weight loss when the segments were recovered with gelatin $8 \%$. The whey protein coating reduced the development of bacteria and of yeasts and molds. The paraffin emulsion increased the development of bacteria and of yeasts and molds. No Salmonella and coliform were detected in the samples The edible coatings were not effective on the maintenance of sensorial characteristics. In general, the edible coatings were little effective on the maintenance of the physiological, 
physico-chemical, microbiological and sensorial characteristics of fresh-cut tangor 'Murcott'..

Key-words: 'Murcott', fresh-cut, edible coatings

\subsection{Introdução}

No mercado brasileiro já são populares os legumes e folhosas frescos preparados, mas as frutas prontas para serem consumidas ainda não são comuns, sendo necessário o conhecimento do comportamento fisiológico destes produtos preparados (Durigan \& Sargent, 1999).

O tangor 'Murcott' possui ótima aceitação no mercado para o consumo in natura, porém, sua casca é relativamente fina e bastante aderida ao fruto, o que dificulta o seu descascamento, tendo assim, um grande potencial de ser comercializado sob a forma de produto minimamente processado.

O corte dos tecidos realizado no preparo dos produtos minimamente processados estimula o aparecimento de mudanças fisiológicas indesejáveis. A integridade celular é perdida, destruindo a compartimentação de enzimas e substratos, tendo como conseqüência a elevação na produção de etileno e na taxa respiratória, além da formação de metabólitos secundários. A senescência pode ser acelerada e odores indesejáveis podem ser desenvolvidos, como resultados do aumento da respiração e produção de etileno (Burns, 1995).

A utilização de baixas temperaturas durante o armazenamento de produtos minimamente processados é a técnica mais útil e importante para a manutenção da qualidade destes produtos.

A utilização de recobrimentos comestíveis é uma das formas de criar uma barreira semipermeável a gases e vapor d'água, reduzindo, assim, a taxa respiratória e a perda de água, garantindo o aumento da vida de prateleira de produtos minimamente processados. Os materiais mais utilizados na 
composição de recobrimentos comestíveis são os lipídios, os polissacarídeos e as proteínas (Baldwin et al., 1995b).

O objetivo deste estudo foi avaliar a eficiência de recobrimentos comestíveis à base de gelatina, concentrado protéico de soro de leite e parafina na redução da taxa respiratória e na manutenção da qualidade microbiológica, sensorial e físico-química de tangor 'Murcott' minimamente processado.

\subsection{Material e métodos}

Tangores 'Murcott' provenientes da região de Engenheiro Coelho - SP foram obtidos numa casa de embalagens desta região e levados para o Laboratório de Pós-Colheita do Departamento de Produção Vegetal da Esalq/USP, onde foram selecionados quanto à ausência de defeitos e danos mecânicos. Os frutos foram lavados com detergente neutro, sanitizados com cloro (200mg. $\mathrm{L}^{-1}$ ) por 10 minutos e armazenados nas temperaturas de estudo por 12 horas.

Decorrido o tempo de armazenamento, os frutos foram submetidos ao processamento mínimo na forma de gomos. Este nível de processamento mínimo foi escolhido por ser o mais conveniente ao consumidor.

Tanto o descascamento quanto a separação dos gomos foram realizados manualmente. Para a separação dos gomos utilizou-se uma espátula para facilitar a separação inicial destes e evitar danos por esmagamento devido à pressão exercida pelas mãos dos processadores. O preparo das amostras foi realizado em sala climatizada $\left(15^{\circ} \mathrm{C}\right)$ e sanitizada, e os processadores estavam devidamente paramentados com máscara, touca, avental e luvas descartáveis próprios para processamento mínimo.

Após o processamento, os gomos foram submetidos aos tratamentos com os seguintes recobrimentos comestíveis: gelatina a $8 \% \mathrm{p} / \mathrm{p}$, gelatina a $4 \%$ $\mathrm{p} / \mathrm{p}$, concentrado protéico de soro de leite a $8 \% \mathrm{p} / \mathrm{p}$ e emulsão à base de parafina Meghwax X-23 (MEGH Ind. e Com. Ltda., São Paulo). A aplicação dos 
recobrimentos foi realizada por imersão. Gomos sem recobrimento foram utilizados como controle.

As amostras foram acondicionadas em bandejas perfuradas de polietileno tereftalato, para que não houvesse modificação da atmosfera do interior da embalagem.

Os tratamentos consistiram dos gomos tratados com diferentes recobrimentos comestíveis armazenados sob as temperaturas de $6^{\circ}$ e $12^{\circ}$ e umidade relativa de 85 a $90 \%$.

\section{- Descrição das análises}

\section{Determinação da taxa respiratória:}

As determinações foram realizadas diariamente, a partir do primeiro dia após o processamento, durante oito dias.

Foram utilizadas amostras de $200 \mathrm{~g}$ do produto minimamente processado, que foram acondicionados em jarros herméticos de vidro herméticos e armazenados sob as temperaturas desejadas. Na tampa de cada frasco foi colocado um septo de silicone através do qual foram retiradas alíquotas de gás de $1 \mathrm{~mL}$ utilizando-se seringa especial.

Essas amostras de ar foram injetadas em Cromatógrafo a Gás, marca Thermoffinigan, modelo Trace 2000 GC equipado com coluna Porapack $\mathrm{N}$ de $2 \mathrm{~m}$ de comprimento, metanador e detetor de ionização de chama (FID). 0 hidrogênio foi utilizado como gás de arraste a $40 \mathrm{~mL} \cdot \mathrm{min}^{-1}$. As temperaturas mantidas no aparelho foram de $100^{\circ} \mathrm{C}$ no injetor, $100^{\circ} \mathrm{C}$ para a coluna, $250^{\circ} \mathrm{C}$ no detetor e $350^{\circ} \mathrm{C}$ no metanador. $\mathrm{O} \mathrm{CO}_{2}$ foi quantificado pela calibração com padrões de $2150 \mu \mathrm{L} . \mathrm{L}^{-1}$ e $29900 \mu \mathrm{L} . \mathrm{L}^{-1}$-de $\mathrm{CO}_{2}$.

Para o cálculo da respiração foram levados em consideração o volume do frasco, a massa dos frutos e o tempo de acúmulo de $\mathrm{CO}_{2}$. A taxa respiratória foi expressa em $\mathrm{mL} \mathrm{CO} \cdot \mathrm{Kg}^{-1} \cdot \mathrm{h}^{-1}$. 
O delineamento experimental utilizado para cada temperatura foi inteiramente casualizado em esquema fatorial $5 \times 8$ (recobrimentos comestíveis e tempo de armazenamento), com 6 repetições por tratamento. Os resultados foram submetidos à análise do erro padrão. As diferenças entre dois tratamentos maiores que a soma de dois erros padrões foram consideradas significativas $(p \leq 0,05)$.

\section{Avaliação das características físico-químicas:}

As análises físico-químicas foram realizadas a cada dois dias por um período de seis dias, quanto a:

a) ácido ascórbico: por titulação com DCFI de acordo com metodologia proposta por Carvalho (1990), utilizando-se suco homogeneizado da amostra. Os resultados foram expressos em $\mathrm{mg}$ de ácido ascórbico/100g de amostra.

b) teor de Sólidos Solúveis: determinado por leitura direta em refratômetro digital Atago, modelo Palete 101, utilizando-se suco homogeneizado da amostra. Os resultados foram expressos em ${ }^{\circ}$ Brix.

c) acidez titulável: de acordo com metodologia proposta por Carvalho (1990), utilizando-se suco homogeneizado da amostra. Os resultados foram expressos em \% de ácido cítrico.

d) "ratio": calculado através da relação sólidos solúveis totais / acidez total titulável.

e) perda de massa fresca: determinada pela diferença, em porcentagem, entre o peso inicial e o peso final após cada período de armazenamento.

f) coloração: determinada com colorímetro Minolta, modelo CR-300, tomandose uma leitura da porção interna dos gomos (que foram divididos ao meio longitudinalmente). As leituras foram realizadas em quatro gomos por repetição e os resultados expressos em luminosidade $(L)$ e cromaticidade (C). 
O delineamento experimental utilizado para cada temperatura foi inteiramente casualizado em esquema fatorial $5 \times 4$ (recobrimentos comestíveis e épocas de avaliação) com 4 repetições. Os resultados foram submetidos à análise conjunta de variância, reunindo as duas temperaturas, e comparação de médias $(p \leq 0,05)$.

\section{Análises microbiológicas:}

As análises microbiológicas foram realizadas no $4^{\circ}$ e $7^{\circ}$ dias de armazenamento, com exceção da contagem total de bolores e leveduras para as amostras armazenadas a $6^{\circ} \mathrm{C}$, a qual foi realizada apenas no $7^{\circ}$ dia de armazenamento.

As análises realizadas foram: contagem total de bactérias psicrotróficas, contagem total de bactérias anaeróbias, contagem total de bolores e leveduras, número mais provável (NMP) de coliformes totais e fecais e presença/ausência de Salmonella.

As análises para contagem de bactérias psicrotróficas, bactérias anaeróbias, bolores e leveduras e para o NMP de coliformes foram efetuadas em porções de $50 \mathrm{~g}$ de fruto para cada repetição, pesados assepticamente e colocadas em erlenmeyers, com $450 \mathrm{~mL}$ de água peptonada $(0,1 \%)$ estéril, constituindo a diluição $10^{-1}$. A partir da diluição $10^{-1}$, obteve-se a diluição $10^{-2}$, pipetando-se $10 \mathrm{~mL}$ da solução $10^{-1} \mathrm{em} 90 \mathrm{~mL}$ de água peptonada esterilizada $(0,1 \%)$ e a partir desta, obteve-se a diluição $10^{-3}$, que serviu de base para a preparação da diluição $10^{-4}$.

A determinação da presença de Salmonella foi a única análise que dispensou o uso de diluições, por ter sido empregada uma metodologia distinta, que será descrita mais adiante.

a) Contagem total de bactérias psicrotróficas

Para contagem de bactérias psicrotróficas (qualquer bactéria cuja temperatura ótima para crescimento situa-se acima de $20^{\circ} \mathrm{C}$, porém toleram e 
crescem sob refrigeração), utilizou-se o meio Ágar Padrão para Contagem (PCA).

O princípio desta metodologia baseia-se na capacidade que cada célula microbiana presente na amostra tem de formar uma colônia visível e isolada, quando fixada em um meio de cultura sólido próprio para o seu desenvolvimento (Silva et al., 2001).

A partir de três diluições dos tangores minimamente processados $\left(10^{-1} \mathrm{a}\right.$ $10^{-3}$ ) foi plaqueado em profundidade $1 \mathrm{~mL}$ de cada diluição em duplicata, utilizando-se $20 \mathrm{~mL}$ de meio de cultura PCA. Após o plaqueamento, as placas permaneceram em repouso até a completa solidificação do meio, sendo então invertidas e incubadas a $7^{\circ} \mathrm{C}$ por 10 dias.

Decorrido o tempo de incubação, foram selecionadas as placas e procedeu-se a contagem das mesmas, com auxílio do contador de colônias Phoenix modelo EC 589.

b) Contagem total de bactérias anaeróbias

Para contagem de bactérias anaeróbias, também se utilizou o meio Ágar Padrão para Contagem (PCA).

A partir da diluição $10^{-1}$ dos tangores minimamente processados foi plaqueado em profundidade $1 \mathrm{~mL}$ da diluição em duplicata, utilizando-se $20 \mathrm{~mL}$ de meio de cultura PCA. Após o plaqueamento, as placas permaneceram em repouso até a completa solidificação do meio, sendo então invertidas e incubadas a $35^{\circ} \mathrm{C}$ por 48 horas em jarra de anaerobiose.

Decorrido o tempo de incubação, foram selecionadas as placas e procedeu-se a contagem das mesmas, com auxílio do contador de colônias Phoenix modelo EC 589.

C) Contagem total de bolores e leveduras

Para contagem de bolores e leveduras, utilizou-se o meio Batata Dextrose Ágar (BDA). 
Foram utilizados $20 \mathrm{~mL}$ de meio BDA para cada placa, que permaneceram em repouso até a completa solidificação do meio. Decorrido este tempo, a partir das quatro diluições dos tangores minimamente processados $\left(10^{-1}\right.$ a $\left.10^{-4}\right)$, efetuou-se o plaqueamento de $0,1 \mathrm{~mL}$ de cada diluição por espalhamento com alça de Drigalsky (superfície). As placas foram, então, incubadas a $30^{\circ}-32^{\circ} \mathrm{C}$ por 3 a 5 dias.

Decorrido o tempo de incubação, foram selecionadas as placas e procedeu-se a contagem das mesmas, com auxílio do contador de colônias Phoenix modelo EC 589.

d) NMP de coliformes totais e fecais

Coliformes totais e fecais foram determinados pelo método do NMP, através da técnica dos Tubos Múltiplos.

A técnica de Tubos Múltiplos conta com duas fases distintas: a fase do teste presuntivo, onde se busca detectar a presença de microorganismos fermentadores de lactose e onde é possível recuperar células injuriadas; e a fase do teste confirmativo, através do qual se determina a população real de coliformes totais e fecais.

Para o teste presuntivo foram utilizadas três séries de cinco tubos de ensaio, os quais continham um tubo de Durham e Caldo Lauril Sulfato Triptose (LST), um meio cuja fonte de carbono é a lactose, que é fermentada pelas bactérias do grupo coliforme, com produção de água e gás.

Em cada tubo da primeira série foi adicionado $1 \mathrm{~mL}$ da diluição $10^{-1}$, e em cada tubo da segunda série foi adicionado $1 \mathrm{~mL}$ da diluição $10^{-2}$, e em cada tubo da terceira série, $1 \mathrm{~mL}$ da diluição $10^{-3}$.

Todos os tubos foram incubados em estufa termostatizada a $35-37^{\circ} \mathrm{C}$, por 24-48h. Após 24 e 48 horas de incubação, sendo positivos os resultados, foi possível observar o esvaziamento dos tubos de Durham, devido à produção de gás pelas bactérias do grupo coliforme ao fermentarem a lactose. 
Alíquotas dos tubos positivos do teste presuntivo foram transferidas para o teste confirmativo, verificando-se, desta forma, se realmente tratavam-se de bactérias do grupo coliforme.

Utilizando-se a alça de níquel-cromo, foram inoculados tubos de Caldo Verde Brilhante Lactose Bile (CVBLB), em concentração simples, e tubos de Caldo EC (específico para Escherichia coli), correspondentes aos tubos positivos da fase anterior.

Os tubos de CVBLB foram incubados em estufa termostatizada à temperatura de $35-37^{\circ} \mathrm{C}$ durante $24-48 \mathrm{~h}$, sendo verificada, após este período, a formação ou não de gás nos tubos de Durham. A formação de gás em CVBLB confirma a presença de bactérias do grupo coliforme, podendo ser de origem fecal ou não, denominadas coliformes totais.

Os tubos de EC, uma vez inoculados, foram incubados em banho-maria termostatizados à temperatura de $45^{\circ} \mathrm{C}$ por 24 horas. A formação de gás em EC, após este período de incubação, confirma a presença de coliformes fecais.

A partir do número de tubos positivos em cada série de ambos os meios, consultando-se seus valores correspondentes na tabela da Associação Brasileira de Normas Técnicas MB 3463, obteve-se o NMP de coliformes totais (CVBLB) e fecais (Caldo EC), por grama de tangor 'Murcott' minimamente processado.

e) Detecção de Salmonella

Para detecção de Salmonella, utilizou-se o kit '1-2 test', fabricado pela BioControl/USA. Trata-se de um método oficial aprovado pela AOAC (Association of Official Analytical Chemists) para utilização em todos os tipos de alimentos.

A detecção foi efetuada em porções de $25 \mathrm{~g}$ de fruto para cada tratamento, pesados assepticamente e colocadas em erlenmeyers, com $225 \mathrm{~mL}$ de água peptonada tamponada esterilizada $(0,1 \%)$. Os frascos foram incubados em estufa termostatizada, a $35^{\circ} \mathrm{C}$ por 24 horas. O pré-aquecimento é 
necessário pela exigência de ausência de Salmonella em $25 \mathrm{~g}$ de qualquer alimento analisado para o consumo humano. Deste modo, se a bactéria estiver presente no alimento, não importando o número de bactérias presentes, o alimento é considerado impróprio para o consumo humano. Com o préaquecimento, sua multiplicação é favorecida, favorecendo a detecção na análise, uma vez que tal patógeno encontra-se normalmente em níveis baixos nos alimentos. Decorrido o período de incubação, fez-se o preparo dos kits, compostos, cada um, de dois compartimentos. A amostra pré-enriquecida foi inoculada na câmara de inoculação $(0,1 \mathrm{~mL})$, onde primeiramente foi adicionada uma gota de solução de iodo-iodeto e depois removido o tampão desta câmara com auxílio de uma pinça estéril. A câmara de motilidade contém um meio de motilidade não seletivo a base de peptona. Esta câmara é fechada por uma pequena ponteira (que foi retirada) para formar um vão no gel, e adicionou-se uma gota da solução de anticorpos polivalentes anti-Salmonella. Incubaram-se os kits a $35^{\circ} \mathrm{C}$ por 24 horas. Após a incubação foi feita a leitura dos resultados.

A possível presença de Salmonella é caracterizada pela formação de uma imunobanda na metade superior do gel na câmara de motilidade. Trata-se de uma banda branca que apresenta forma de $U$, formada pela aglutinação das células da bactéria com a solução de anticorpos.

Os resultados foram expressos em UFC/g de produto para bactérias psicrotróficas, bactérias anaeróbias e bolores e leveduras, NMP/g para coliformes totais e fecais e presença ou ausência de Salmonella em $25 \mathrm{~g}$ de produto. 


\section{Avaliação das características sensoriais:}

Estas análises foram realizadas no $4^{\circ}$ dia após o processamento por uma equipe de 20 provadores para cada temperatura estudada. Foi utilizado o teste de ordenação de preferência para aparência, aroma e sabor para as amostras armazenadas a $6^{\circ} \mathrm{C}$ e para aparência e odor para as amostras armazenadas a $12^{\circ} \mathrm{C}$, onde cada um dos provadores indicou, em ordem decrescente, qual a amostra preferida por ele para cada um dos três atributos avaliados. Para a melhor amostra de cada atributo, foi atribuída a nota 1 e para a pior amostra, a nota 5. As notas atribuídas pelos provadores para um determinado tratamento foram, então, somadas, obtendo assim a soma das ordens para cada tratamento.

O delineamento experimental utilizado para cada temperatura foi inteiramente casualizado, e os tratamentos consistiram nos cinco recobrimentos utilizados. Os resultados foram calculados pela soma das ordens para cada tratamento e avaliados estatisticamente pelo teste de Friedman, utilizando-se os dados da tabela de Newell e MacFarlane (1987), citado por Silva (1997).

\subsection{Resultados e discussão}

\subsubsection{Taxa respiratória}

Para as amostras armazenadas a $6^{\circ} \mathrm{C}$, no primeiro dia após 0 processamento foi observada a maior taxa respiratória, que variou de 5,5 $\mathrm{mLCO} 2 \cdot \mathrm{kg}^{-1} \cdot \mathrm{h}^{-1}$ a $11 \mathrm{mLCO} \cdot \mathrm{kg}^{-1} \cdot \mathrm{h}^{-1}$. No segundo dia de armazenamento houve estabilização da taxa respiratória de todos os tratamentos e os valores observados a partir deste momento variaram de $2,8 \mathrm{mLCO}_{2} \cdot \mathrm{kg}^{-1} \cdot \mathrm{h}^{-1}$ a 3,7 $\mathrm{mLCO} 2 \cdot \mathrm{kg}^{-1} \cdot \mathrm{h}^{-1}$ (Figura 1). 


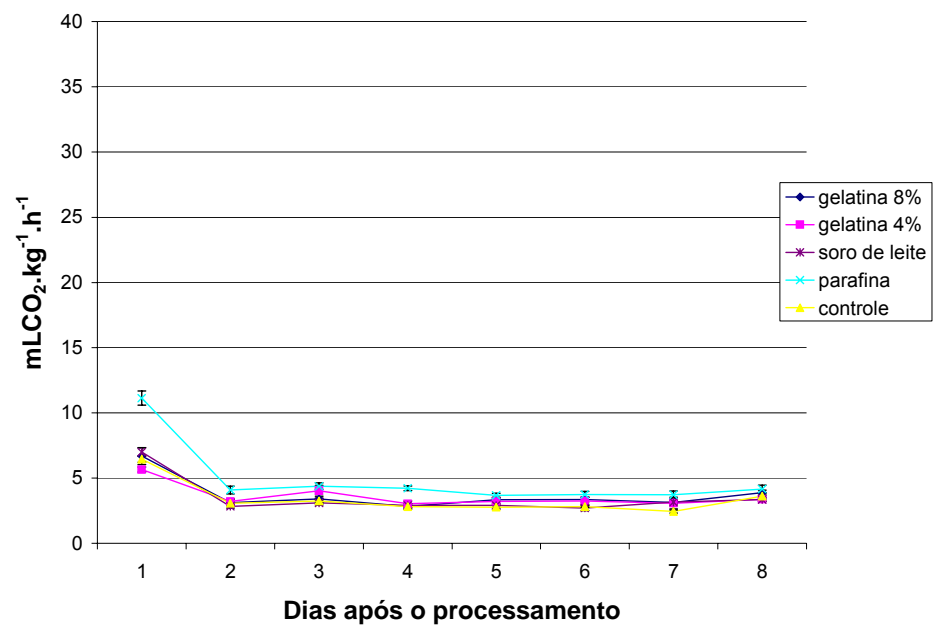

Figura 1 - Taxa respiratória de tangores 'Murcott' minimamente processados em gomos, armazenados a $6^{\circ} \mathrm{C}$ em função do recobrimento comestível. Barras verticais representam erro padrão da média

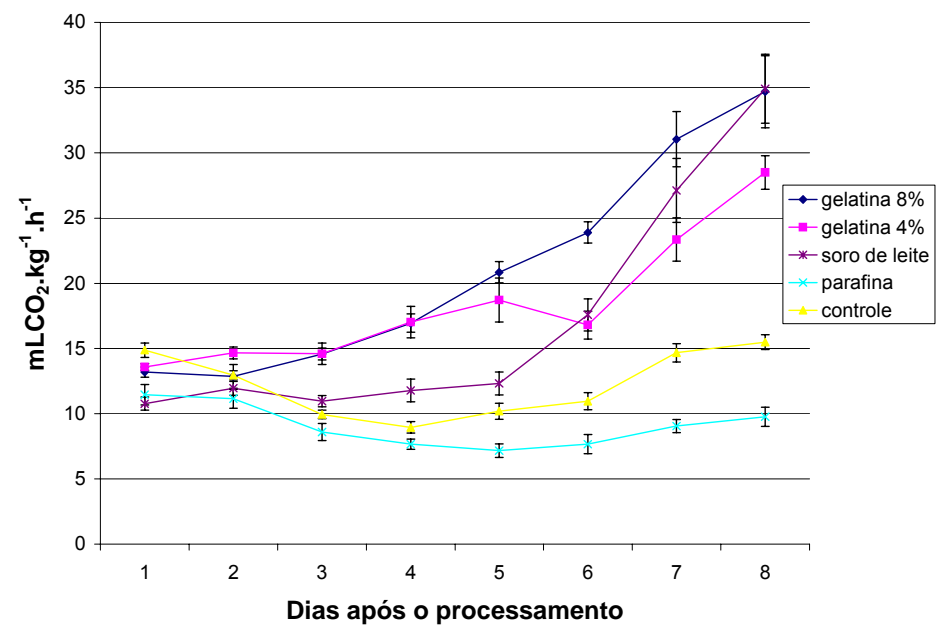

Figura 2 - Taxa respiratória de tangores 'Murcott' minimamente processados em gomos, armazenados a $12^{\circ} \mathrm{C}$ em função do recobrimento comestível. Barras verticais representam erro padrão da média

O aumento da temperatura de armazenamento causou elevação significativa na taxa respiratória dos gomos de tangor 'Murcott' para todos os tratamentos avaliados (Figuras 1 e 2). 
Quando armazenados a $12^{\circ} \mathrm{C}$, os frutos apresentaram taxa respiratória estável até o $2^{\circ}$ dia após o processamento, que variou de $11 \mathrm{mLCO} \cdot \mathrm{kg}^{-1} \cdot \mathrm{h}^{-1} \mathrm{a}$ $15 \mathrm{mLCO} 2 \cdot \mathrm{kg}^{-1} \cdot \mathrm{h}^{-1}$. A partir de então, houve aumento na taxa respiratória para todos os tratamentos, com exceção dos gomos controle e dos tratados com parafina, alcançando valores de $35 \mathrm{mLCO} 2 \cdot \mathrm{kg}^{-1} \cdot \mathrm{h}^{-1}$. Os gomos tratados com parafina mantiveram a respiração praticamente estável durante todo o período de avaliação, com valores que variaram de $7 \quad \mathrm{mLCO}_{2} \cdot \mathrm{kg}^{-1} \cdot \mathrm{h}^{-1}$ a 11 $\mathrm{mLCO}_{2} \cdot \mathrm{kg}^{-1} \cdot \mathrm{h}^{-1}$ (Figura 2).

O efeito da utilização de parafina para reduzir a taxa respiratória de gomos de tangor 'Murcott' foi mais eficiente que os recobrimentos protéicos quando as amostras foram armazenadas a $12^{\circ} \mathrm{C}$. Este comportamento pode ser explicado pela baixa taxa respiratória apresentada pelos frutos cítricos (5 a 10 $\left.\mathrm{mgCO}_{2} \cdot \mathrm{kg}^{-1} \cdot \mathrm{h}^{-1}\right)$, que é ainda mais reduzida quando estes frutos são armazenados sob baixas temperaturas, o que pode mascarar o efeito da barreira aos gases criada pelos recobrimentos. Os recobrimentos lipídicos, além de prevenir a perda de água, têm sido utilizados para reduzir a respiração dos produtos, estendendo sua vida de prateleira (Kester \& Fennema, 1986).

\subsubsection{Análises físico-químicas}

\subsubsection{1 Ácido ascórbico}

A utilização de recobrimentos comestíveis não impediu que houvesse redução nos teores de ácido ascórbico dos tangores minimamente processados durante o armazenamento (Tabela 1). O ácido ascórbico pode ser oxidado por uma série de mecanismos bioquímicos que são responsáveis não só pela perda de sua atividade vitamínica como também pela formação de pigmentos escuros. Diferentes enzimas podem catalisar sua degradação direta (ácido ascórbico oxidase), ou indireta (peroxidase, polifenoloxidase e citocromo oxidase). O corte 
dos tecidos aumenta a atividade enzimática, resultando em perda rápida do ácido ascórbico pelos produtos minimamente processados (Chitarra, 1998).

De maneira geral, os teores deste ácido não foram influenciados pela temperatura (Tabela 1).

Os teores de ácido ascórbico dos frutos armazenados a $6^{\circ}$ e $12^{\circ} \mathrm{C}$ apresentaram redução de 25,62 e 33,50\%, respectivamente após seis dias de armazenamento. Estes resultados estão de acordo com os obtidos por Rocha et al. (1995), que também observaram decréscimo de $36 \%$ nos teores de ácido ascórbico de laranjas minimamente processadas armazenadas a $4^{\circ} \mathrm{C}$ por 11 dias, no entanto, contradizem Vilas Boas et al. (2000), que não detectaram redução no teor de vitamina C de tangerinas 'Ponkan' após seu descascamento.

Tabela 1. Teor de ácido ascórbico (mg /100g de amostra) de tangor 'Murcott' minimamente processado tratado com recobrimentos comestíveis e armazenado sob duas temperaturas

\begin{tabular}{lccc}
\hline Dias de & \multicolumn{2}{c}{ Temperatura } & \\
armazenamento & $6^{\circ} \mathrm{C}$ & $12^{\circ} \mathrm{C}$ & Média \\
\hline 0 & $25,94 \mathrm{a} \mathrm{A}$ & $25,94 \mathrm{a} \mathrm{A}$ & $25,94 \mathrm{a}$ \\
2 & $21,43 \mathrm{~b} \mathrm{~A}$ & $19,57 \mathrm{c} \mathrm{B}$ & $20,50 \mathrm{~b}$ \\
4 & $20,47 \mathrm{~b} \mathrm{~A}$ & $21,60 \mathrm{~b} \mathrm{~A}$ & $21,04 \mathrm{~b}$ \\
6 & $20,65 \mathrm{~b} \mathrm{~A}$ & $19,43 \mathrm{c} \mathrm{A}$ & $20,04 \mathrm{~b}$ \\
Média & $22,12 \mathrm{~A}$ & $21,64 \mathrm{~A}$ & \\
\hline
\end{tabular}

Médias seguidas da mesma letra minúscula na coluna e maiúscula na linha não diferem entre $s i$, pelo teste de Tukey $(p \leq 0,05)$.

${ }^{1}$ Os valores são referentes à média de ácido ascórbico obtida entre os diferentes recobrimentos comestíveis. 


\subsubsection{Sólidos solúveis}

No geral, a temperatura de armazenamento não influenciou os teores de sólidos solúveis, no entanto, para os gomos tratados com gelatina a $8 \%$, os teores de sólidos solúveis foram significativamente maiores quando armazenados a $12^{\circ} \mathrm{C}$ do que a $6^{\circ} \mathrm{C}$. No entanto, para os demais tipos de recobrimentos, não houve efeito da temperatura sobre esta variável. Frutos cítricos possuem padrão de atividade respiratória do tipo não climatérico, o que indica que ocorrem poucas mudanças na qualidade interna destes frutos após a colheita, sendo assim, a detecção de mudanças decorrentes do processamento mínimo é dificultada.

Tabela 2. Teor de sólidos solúveis ('Brix) de tangor 'Murcott' minimamente processado tratado com recobrimentos comestíveis e armazenado sob duas temperaturas ${ }^{1}$

\begin{tabular}{lccc}
\hline $\begin{array}{l}\text { Recobrimentos } \\
\text { comestíveis }\end{array}$ & \multicolumn{2}{c}{ Temperatura } & \\
\hline Controle & $12,03 \mathrm{~b} \mathrm{~A}$ & $12,18 \mathrm{ab} \mathrm{A}$ & $12,10 \mathrm{~b}$ \\
Gelatina 8\% & $11,42 \mathrm{c} \mathrm{B}$ & $11,98 \mathrm{ab} \mathrm{A}$ & $11,70 \mathrm{c}$ \\
Gelatina 4\% & $11,97 \mathrm{~b} \mathrm{~A}$ & $11,68 \mathrm{~b} \mathrm{~A}$ & $11,82 \mathrm{bc}$ \\
Soro de leite 8\% & $12,13 \mathrm{~b} \mathrm{~A}$ & $11,88 \mathrm{~b} \mathrm{~A}$ & $12,00 \mathrm{bc}$ \\
Parafina & $12,78 \mathrm{a} \mathrm{A}$ & $12,44 \mathrm{a} \mathrm{A}$ & $12,61 \mathrm{a}$ \\
Média & $12,07 \mathrm{~A}$ & $12,03 \mathrm{~A}$ & \\
\hline
\end{tabular}

Médias seguidas da mesma letra minúscula na coluna e maiúscula na linha não diferem entre si, pelo teste de Tukey $(p \leq 0,05)$.

${ }^{1}$ Os valores são referentes à média de sólidos solúveis obtida entre os diferentes tempos de avaliação.

Os gomos recobertos com emulsão à base de parafina apresentaram os maiores teores de sólidos solúveis durante o período de armazenamento. Por outro lado, os gomos recobertos com gelatina a $8 \%$ apresentaram teores de 
sólidos solúveis significativamente menores que o controle e o tratamento com parafina (Tabelas 2 e 3). Apesar das diferenças apresentadas serem estatisticamente significativas, em termos de qualidade do produto estas diferenças são pequenas, não havendo, portanto, prejuízo da qualidade organoléptica.

De maneira geral, o período de armazenamento não teve influência nos teores de sólidos solúveis (Tabela 3 ).

Tabela 3. Teor de sólidos solúveis ('Brix) de tangor 'Murcott' minimamente processado tratado com recobrimentos comestíveis ${ }^{1}$

\begin{tabular}{|c|c|c|c|c|c|}
\hline \multirow{2}{*}{$\begin{array}{l}\text { Recobrimentos } \\
\text { comestíveis }\end{array}$} & \multicolumn{4}{|c|}{ Dias de armazenamento } & \multirow[b]{2}{*}{ Média } \\
\hline & 0 & 2 & 4 & 6 & \\
\hline Controle & 12,15 a $A$ & $12,15 \mathrm{ab} A$ & $12,10 \mathrm{~b} \mathrm{~A}$ & $12,01 \mathrm{~b} \mathrm{~A}$ & $12,10 \mathrm{~b}$ \\
\hline Gelatina 8\% & 12,15 a $A$ & 11,64 b $A B$ & $11,56 \mathrm{~b} A B$ & 11,45 b B & $11,70 \mathrm{c}$ \\
\hline Gelatina $4 \%$ & 12,15 a $A$ & $11,73 \mathrm{~b} \mathrm{~A}$ & 11,71 b A & 11,71 b A & $11,82 \mathrm{bc}$ \\
\hline Soro de leite $8 \%$ & 12,15 a $A$ & $11,94 a b A$ & $12,27 \mathrm{ab} A$ & 11,64 b A & $12,00 \mathrm{bc}$ \\
\hline Parafina & 12,15 a $A$ & 12,59 a $A B$ & 12,89 a $A B$ & 12,82 a B & $12,61 \mathrm{a}$ \\
\hline Média & $12,15 \mathrm{~A}$ & $12,01 \mathrm{~A}$ & $12,11 \mathrm{~A}$ & $11,93 \mathrm{~A}$ & \\
\hline
\end{tabular}

\subsubsection{Acidez titulável e "ratio"}

As variáveis acidez titulável e "ratio" apresentaram interação significativa entre os tipos de recobrimentos comestíveis e a temperatura de armazenamento (Tabelas 4 e 5). Para estas variáveis houve também efeito significativo do tempo de armazenamento (Tabela 6). 
De maneira geral, a temperatura de armazenamento e o tipo de recobrimento utilizado não exerceram efeito sobre a acidez titulável, porém, para os gomos recobertos com parafina, o aumento na temperatura de armazenamento de $6^{\circ} \mathrm{C}$ para $12^{\circ} \mathrm{C}$ causou diminuição da acidez titulável (Tabela 4), o que pode ser explicado pela maior taxa respiratória das amostras quando armazenadas a $12^{\circ} \mathrm{C}$. $\mathrm{O}$ aumento na taxa respiratória implica num maior consumo de substratos, e entre os substratos utilizados pelos tecidos vegetais para a respiração estão os ácidos orgânicos.

Lamikanra et al. (2000) estudaram as mudanças na qualidade de melão minimamente processado durante o armazenamento a $4^{\circ}$ e $20^{\circ} \mathrm{C}$ e observaram estabilidade nos teores de sólidos solúveis e de acidez quando os melões foram armazenados sob baixa temperatura $\left(4^{\circ} \mathrm{C}\right)$.

Tabela 4. Valores médios de acidez titulável (g de ácido cítrico/100g de amostra) de tangor 'Murcott' minimamente processado tratado com recobrimentos comestíveis e armazenado sob duas temperaturas ${ }^{1}$

\begin{tabular}{lccc}
\hline Recobrimentos & \multicolumn{2}{c}{ Temperatura } & Média \\
comestíveis & $6^{\circ} \mathrm{C}$ & $12^{\circ} \mathrm{C}$ & $0,61 \mathrm{a}$ \\
\hline Controle & $0,62 \mathrm{ab} \mathrm{A}$ & $0,61 \mathrm{a} \mathrm{A}$ & $0,59 \mathrm{a}$ \\
Gelatina 8\% & $0,58 \mathrm{~b} \mathrm{~A}$ & $0,60 \mathrm{a} \mathrm{A}$ & $0,58 \mathrm{a}$ \\
Gelatina 4\% & $0,58 \mathrm{~b} \mathrm{~A}$ & $0,58 \mathrm{ab} \mathrm{A}$ & $0,60 \mathrm{a}$ \\
Soro de leite 8\% & $0,60 \mathrm{ab} \mathrm{A}$ & $0,60 \mathrm{a} \mathrm{A}$ & $0,59 \mathrm{a}$ \\
Parafina & $0,64 \mathrm{a} \mathrm{A}$ & $0,53 \mathrm{~b} \mathrm{~B}$ & \\
Média & $0,60 \mathrm{~A}$ & $0,58 \mathrm{~A}$ &
\end{tabular}

Médias seguidas da mesma letra minúscula na coluna e maiúscula na linha não diferem entre si, pelo teste de Tukey $(p \leq 0,05)$.

${ }^{1}$ Os valores são referentes à média de acidez titulável obtida entre os diferentes tempos de avaliação.

O tipo de recobrimento comestível utilizado para gomos de tangor 'Murcott' teve efeito significativo sobre os valores médios de "ratio". Os gomos 
recobertos com parafina apresentaram valores significativamente maiores do que os gomos controle e daqueles recobertos com gelatina a $8 \%$ e concentrado protéico de soro de leite a $8 \%$ (Tabela 5).

A temperatura de armazenamento também exerceu efeito significativo sobre esta variável, sendo que as amostras armazenadas a $12^{\circ} \mathrm{C}$ apresentaram valores médios de "ratio" significativamente maiores do que as amostras armazenadas a $6^{\circ} \mathrm{C}$ (Tabela 5). O efeito da temperatura foi mais pronunciado nas amostras recobertas com parafina. O aumento dos valores de "ratio" observado com o aumento da temperatura de armazenamento também pode ser explicado pelo aumento da respiração e, consequentemente, pelo consumo de ácidos orgânicos. A diminuição dos teores de ácidos orgânicos aumenta esta relação.

Tabela 5. Valores médios de "ratio" (sólidos solúveis/acidez titulável) de tangor 'Murcott' minimamente processado tratado com recobrimentos comestíveis e armazenado sob duas temperaturas ${ }^{1}$

\begin{tabular}{lccc}
\hline Recobrimentos & \multicolumn{2}{c}{ Temperatura } & \\
comestíveis & $6^{\circ} \mathrm{C}$ & $12^{\circ} \mathrm{C}$ & Média \\
\hline Controle & 19,58 a A & $20,10 \mathrm{~b} \mathrm{~A}$ & $19,84 \mathrm{~b}$ \\
Gelatina 8\% & $20,08 \mathrm{a} \mathrm{A}$ & $20,38 \mathrm{~b} \mathrm{~A}$ & $20,23 \mathrm{~b}$ \\
Gelatina 4\% & 20,97 a A & $20,36 \mathrm{~b} \mathrm{~A}$ & $20,66 \mathrm{ab}$ \\
Soro de leite 8\% & 20,53 a A & $19,92 \mathrm{~b} \mathrm{~A}$ & $20,22 \mathrm{~b}$ \\
Parafina & 20,01 a B & 23,99 a A & 22,00 a \\
Média & $20,23 \mathrm{~B}$ & $20,95 \mathrm{~A}$ & \\
\hline
\end{tabular}

Médias seguidas da mesma letra minúscula na coluna e maiúscula na linha não diferem entre si, pelo teste de Tukey $(p \leq 0,05)$.

${ }^{1}$ Os valores são referentes à média de "ratio" obtida entre os diferentes tempos de avaliação.

Os tangores minimamente processados apresentaram, em média, diminuição da acidez titulável e correspondente aumento de "ratio", ao longo do 
período de armazenamento, o que sugere que com o decorrer do armazenamento os ácidos orgânicos são consumidos pela atividade respiratória (Tabela 6).

Tabela 6. Valores médios de acidez titulável e "ratio" de tangor 'Murcott' minimamente processado tratado com recobrimentos comestíveis e armazenado sob duas temperaturas ${ }^{1}$

\begin{tabular}{lll}
\hline $\begin{array}{l}\text { Dias de } \\
\text { armazenamento }\end{array}$ & Acidez & \\
\hline 0 & $0,65 \mathrm{a}$ & $19,02 \mathrm{~b}$ \\
2 & $0,59 \mathrm{~b}$ & $20,59 \mathrm{a}$ \\
4 & $0,58 \mathrm{~b}$ & $21,12 \mathrm{a}$ \\
6 & $0,56 \mathrm{~b}$ & $21,63 \mathrm{a}$ \\
\hline
\end{tabular}

Médias seguidas da mesma letra na coluna não diferem entre si, pelo teste de Tukey $(p \leq 0,05)$.

'Os valores são referentes à média de acidez titulável e "ratio" obtida entre diferentes recobrimentos comestíveis e temperaturas de armazenamento.

Estes resultados estão de acordo com aqueles encontrados por Rocha et al. (1995), que observaram redução na acidez titulável de laranjas minimamente processadas no decorrer de 13 dias de armazenamento a $4^{\circ} \mathrm{C}$, porém $\mathrm{o}$ decréscimo observado por estes autores foi mais acentuado, ocorrendo queda de $0,46 \%$ para $0,29 \%$. Estes autores também relatam que, a despeito da queda nos teores de ácidos orgânicos, não houve mudança significativa dos valores de $\mathrm{pH}$ durante o armazenamento.

No entanto, os resultados obtidos discordam daqueles encontrados por Pretel et al. (1998), que não observaram mudanças nos teores de acidez de laranjas minimamente processadas armazenadas a $4^{\circ} \mathrm{C}$ por 11 dias. 


\subsubsection{Perda de massa fresca}

Houve aumento gradual e significativo da perda de massa fresca das amostras, com o decorrer do período de armazenamento. Ao final do período de armazenamento, as amostras apresentaram, em média, redução de 2,4\% de suas massas (Tabelas 7 e 8 ).

A temperatura de armazenamento teve efeito sobre a perda de massa das amostras. As amostras armazenadas a $12^{\circ} \mathrm{C}$ tiveram perda de massa fresca significativamente menor que as amostras armazenadas a $6^{\circ} \mathrm{C}$ ao fim do período de armazenamento (Tabela 7). No entanto, a diferença observada, apesar de ser significativa, foi muito pequena, não tendo influência na aparência ou textura do produto. Estes resultados discordam de Brecht (1995), que afirma que quanto menor a temperatura de armazenamento, menor é a perda de massa dos produtos minimamente processados.

Tabela 7. Valores médios de perda de massa fresca (\%) de tangor 'Murcott' minimamente processado tratado com recobrimentos comestíveis, durante armazenamento refrigerado ${ }^{1}$

\begin{tabular}{lccl}
\hline Dias de & \multicolumn{2}{c}{ Temperatura } \\
armazenamento & $6^{\circ} \mathrm{C}$ & $12^{\circ} \mathrm{C}$ & Média \\
\hline 0 & $0,00 \mathrm{~d} \mathrm{~A}$ & $0,00 \mathrm{~d} \mathrm{~A}$ & $0,00 \mathrm{~d}$ \\
2 & $0,59 \mathrm{c} \mathrm{A}$ & $0,45 \mathrm{c} \mathrm{A}$ & $0,52 \mathrm{c}$ \\
4 & $1,69 \mathrm{~b} \mathrm{~A}$ & $1,39 \mathrm{~b} \mathrm{~B}$ & $1,54 \mathrm{~b}$ \\
6 & $2,55 \mathrm{a} \mathrm{A}$ & $2,24 \mathrm{a} \mathrm{B}$ & $2,40 \mathrm{a}$
\end{tabular}

Médias seguidas da mesma letra minúscula na coluna e maiúscula na linha não diferem entre si, pelo teste de Tukey $(p \leq 0,05)$.

${ }^{1}$ Os valores são referentes à média de perda de massa fresca obtida entre os diferentes recobrimentos comestíveis.

A utilização de recobrimentos comestíveis não foi efetiva em reduzir a perda de massa de tangor 'Murcott' minimamente processado. O tratamento 
dos gomos com gelatina, principalmente a $8 \%$, aumentou a perda de massa das amostras. Embora os recobrimentos lipídicos sejam considerados boas barreiras ao vapor de água, as amostras tratadas com emulsão de parafina tiveram perda de massa igual ao controle(Tabela 8). Estes resultados podem ser explicados pela afinidade destes recobrimentos com a água, uma vez que os recobrimentos lipídicos (parafina) são hidrofóbicos, funcionando como boas barreiras ao vapor de água, enquanto os recobrimentos protéicos são hidrofílicos, não sendo boas barreiras à água.

Tabela 8. Valores médios de perda de massa fresca (\%) de tangor 'Murcott' minimamente processado com recobrimentos comestíveis ${ }^{1}$

\begin{tabular}{lcccc}
\hline $\begin{array}{l}\text { Recobrimentos } \\
\text { comestíveis }\end{array}$ & 1 & \multicolumn{4}{c}{ Dias de armazenamento } \\
& 0,00 a D & 0,53 a C & 1,50 ab B & 2,38 bc A \\
\hline Controle & 0,00 a D & 0,60 a C & 1,81 a B & 2,83 a A \\
Gelatina 8\% & 0,00 a D & 0,53 a C & 1,56 ab B & 2,42 b A \\
Gelatina 4\% & 0,00 a D & 0,47 a C & 1,44 b B & 2,26 bc A \\
Soro de leite 8\% & 0,00 a D & 0,48 a C & 1,39 b B & 2,09 c A \\
Parafina & 0,00 D & 0,52 C & 1,54 B & 2,40 A \\
Média & & &
\end{tabular}

Médias seguidas da mesma letra minúscula na coluna e maiúscula na linha não diferem entre si, pelo teste de Tukey $(p \leq 0,05)$.

${ }^{1}$ Os valores são referentes à média de perda de massa fresca obtida entre as diferentes temperaturas de armazenamento.

\subsubsection{Coloração}

No segundo dia após o processamento, os gomos de tangor 'Murcott' apresentaram queda significativa nos valores de luminosidade (L), que se mantiveram sem diferenças significativas, a partir deste momento, até o fim do período de análise. A redução do valor $L$ indica que houve escurecimento das 
amostras. Os valores de cromaticidade (C) apresentaram aumento significativo entre o dia do processamento e o segundo dia de armazenamento. No quarto e sexto dias após o processamento, os valores de $\mathrm{C}$ apresentaram queda significativa em relação ao segundo dia, não diferindo, contudo, entre si (Tabela 9). O valor $C$ indica a intensidade da cor.

Tabela 9. Valores médios de luminosidade (L) e cromaticidade (C) de tangor 'Murcott' minimamente processado com recobrimentos comestíveis, armazenados sob duas temperaturas ${ }^{1}$

\begin{tabular}{lcc}
\hline $\begin{array}{l}\text { Dias de } \\
\text { armazenamento }\end{array}$ & $\mathrm{L}$ \\
\hline 0 & $41,63 \mathrm{a}$ & $26,63 \mathrm{C}$ \\
2 & $39,73 \mathrm{~b}$ & $33,33 \mathrm{a}$ \\
4 & $39,76 \mathrm{~b}$ & $31,92 \mathrm{~b}$ \\
6 & $39,21 \mathrm{~b}$ & $32,00 \mathrm{~b}$
\end{tabular}

Médias seguidas da mesma letra na coluna não diferem entre si, pelo teste de Tukey $(\mathrm{p} \leq 0,05)$.

${ }^{1}$ Os valores são referentes à média de luminosidade e cromaticidade obtida entre diferentes recobrimentos comestíveis e temperaturas de armazenamento.

Estes dados não estão de acordo com os encontrados por Rocha e seus colaboradores (1995), que não observaram mudanças significativas na coloração de laranjas minimamente processadas armazenadas a $4^{\circ} \mathrm{C}$.

A mudança de coloração nos produtos minimamente processados está relacionada com a oxidação de substratos por oxidases (polifenoloxidase, peroxidase, oxidase do ácido ascórbico, entre outras) (Chitarra, 1998). Um dos substratos oxidados em frutos cítricos é o ácido ascórbico. Sua oxidação produz pigmentos escuros, responsáveis pela queda dos valores de L. 


\subsubsection{Análises microbiológicas}

A contagem de bactérias psicrotróficas das amostras armazenadas a $6^{\circ} \mathrm{C}$ foi baixa nos dois dias de análise, exceto para amostras tratadas com parafina, que apresentaram contagem da ordem $10^{5} \mathrm{UFC} / \mathrm{g}$ no $7^{\circ}$ dia de armazenamento. Para as amostras armazenadas a $12^{\circ} \mathrm{C}$, o controle e aquelas tratadas com gelatina a $8 \%$ e concentrado protéico de soro de leite apresentaram baixa contagem total de bactérias psicrotróficas no $4^{\circ}$ e $7^{\circ}$ dia de análise. Os demais tratamentos apresentaram contagem alta, que variou da ordem de $10^{5}$ a $10^{7}$ UFC/g (Tabela 10).

A operação de preparo dos recobrimentos comestíveis pode ter influenciado na contagem microbiana das amostras. As amostras recobertas com emulsão de parafina apresentaram as maiores contagens para bactérias psicrotróficas. A emulsão à base de parafina utilizada é uma cera comercial, e não se tem informações sobre os cuidados tomados pela empresa para evitar a contaminação microbiológica deste produto durante sua fabricação. Por outro lado, as amostras recobertas com concentrado protéico de soro de leite e gelatina a $8 \%$, que sofreram tratamento térmico durante o preparo de $90^{\circ} \mathrm{C}$ por 30 minutos e de $74^{\circ} \mathrm{C}$ por 10 minutos, respectivamente, apresentaram as menores contagens para este tipo de bactéria no $7^{\circ}$ dia de armazenamento. As altas temperaturas a que foram submetidos estas soluções foram responsáveis pela redução da população microbiana nas amostras tratadas com estes recobrimentos.

A Agência Nacional de Vigilância Sanitária não estabelece níveis máximos de bactérias psicrotróficas para frutas ou hortaliças, no entanto, contagens microbianas da ordem de $10^{5}-10^{6}$ UFC/g são consideradas altas, o que pode limitar o consumo destes produtos. 
Tabela 10. Contagem total de bactérias psicrotróficas, em tangor 'Murcott' minimamente processado armazenado a $6^{\circ}$ e $12^{\circ} \mathrm{C}$, utilizando-se a metodologia convencional (PCA)

\begin{tabular}{lcccc}
\hline Recobrimentos & \multicolumn{2}{c}{ Dias de armazenamento a $6^{\circ} \mathrm{C}$} & \multicolumn{2}{c}{ Dias de armazenamento a $12^{\circ} \mathrm{C}$} \\
& 4 & 7 & 4 & 7 \\
\hline Controle & $4,0 \times 10$ & $7,0 \times 10$ & $2,4 \times 10^{4}$ & $3,7 \times 10^{4}$ \\
Gelatina 8\% & $1,5 \times 10$ & $4,0 \times 10$ & $2,0 \times 10$ & $8,0 \times 10^{2}$ \\
Gelatina 4\% & $1,0 \times 10$ & $2,0 \times 10$ & $2,8 \times 10^{5}$ & $6,0 \times 10^{6}$ \\
Soro de leite 8\% & $2,0 \times 10$ & $5,0 \times 10$ & $2,0 \times 10$ & $3,0 \times 10^{2}$ \\
Parafina & $2,0 \times 10^{4}$ & $1,1 \times 10^{5}$ & $5,5 \times 10^{5}$ & $3,0 \times 10^{7}$ \\
\hline
\end{tabular}

Os resultados obtidos representam a média aritmética das duplicatas, expressos em UFC (unidades formadoras de colônias)/g de produto.

Com relação às bactérias anaeróbias, as contagens apresentadas são consideradas baixas (Tabela 11). Provavelmente os recobrimentos comestíveis não levaram a uma modificação muito drástica da atmosfera interna dos frutos, não levando a condições anaeróbicas, o que limitou o desenvolvimento deste tipo de bactéria.

Tabela 11. Contagem total de bactérias anaeróbias, em tangor 'Murcott' minimamente processado armazenado a $6^{\circ}$ e $12^{\circ} \mathrm{C}$, utilizando-se a metodologia convencional (PCA)

\begin{tabular}{lcccc}
\hline Recobrimentos & \multicolumn{2}{c}{ Dias de armazenamento a $6^{\circ} \mathrm{C}$} & \multicolumn{2}{c}{ Dias de armazenamento a $12^{\circ} \mathrm{C}$} \\
Comestíveis & 4 & 7 & 4 & 7 \\
\hline Controle & $1,5 \times 10$ & $3,5 \times 10$ & $2,8 \times 10^{2}$ & $2,7 \times 10^{3}$ \\
Gelatina 8\% & $2,0 \times 10$ & $2,5 \times 10$ & $1,5 \times 10$ & $3,0 \times 10$ \\
Gelatina 4\% & $1,1 \times 10^{2}$ & $9,0 \times 10$ & $1,3 \times 10^{3}$ & $2,8 \times 10^{3}$ \\
Soro de leite 8\% & $2,5 \times 10$ & $2,0 \times 10$ & $2,0 \times 10$ & $2,0 \times 10$ \\
Parafina & $<10$ & $2,0 \times 10^{2}$ & $3,5 \times 10$ & $6,5 \times 10^{2}$ \\
\hline
\end{tabular}

Os resultados obtidos representam a média aritmética das duplicatas, expressos em UFC (unidades formadoras de colônias)/g de produto. 
A contagem total de bolores e leveduras obtida para as amostras armazenadas a $6^{\circ} \mathrm{C}$ apresentou-se baixa no $7^{\circ}$ dia de armazenamento. Para as amostras a $12^{\circ} \mathrm{C}$ obteve-se contagem alta apenas no tratamento com parafina no $4^{\circ}$ dia de armazenamento. No $7^{\circ}$ dia, além da parafina, o tratamento com gelatina a $4 \%$ também apresentou contagem alta para este tipo de microorganismo (Tabela 12). A baixa contagem observada para as amostras tratadas com soro de leite pode ser explicada pela alta temperatura a que foi submetido este recobrimento durante o seu preparo $\left(90^{\circ} \mathrm{C}\right.$ por 30 minutos), que foi responsável pela redução da população microbiana neste tratamento. A ANVISA não impõe limites à contagem de bolores e leveduras em frutas e hortaliças, porém, os altos valores encontrados podem restringir o consumo deste produto.

Tabela 12. Contagem total de bolores e leveduras, em tangor 'Murcott' minimamente processado armazenado a $6^{\circ}$ e $12^{\circ} \mathrm{C}$, utilizando-se a metodologia convencional (BDA)

\begin{tabular}{lccc}
\hline Recobrimentos & Dias de armazenamento a $6^{\circ} \mathrm{C}$ & \multicolumn{2}{c}{ Dias de armazenamento a $12^{\circ} \mathrm{C}$} \\
Comestíveis & 7 & 4 & 7 \\
\hline Controle & $2,7 \times 10^{3}$ & $1,9 \times 10^{4}$ & $4,8 \times 10^{4}$ \\
Gelatina 8\% & $3,4 \times 10^{3}$ & $2,0 \times 10$ & $4,4 \times 10^{4}$ \\
Gelatina 4\% & $2,0 \times 10^{3}$ & $4,4 \times 10^{4}$ & $5,0 \times 10^{6}$ \\
Soro de leite 8\% & $6,2 \times 10^{3}$ & $2,5 \times 10$ & $2,0 \times 10^{2}$ \\
Parafina & $3,7 \times 10^{4}$ & $6,5 \times 10^{5}$ & $4,0 \times 10^{7}$ \\
\hline
\end{tabular}

Resultados expressos em UFC (unidades formadoras de colônias)/g de produto.

Em nenhuma das amostras analisadas houve detecção de coliformes totais, de coliformes fecais ou de Salmonella (Tabelas 13, 14 e 15). Estes resultados estão de acordo com o limite estabelecido pela resolução RDC $n^{\circ} 12$ de 02 de janeiro de 2001 da Agência Nacional de Vigilância Sanitária do Ministério da Saúde, que estabelece que frutas frescas preparadas 
(descascadas, selecionadas ou fracionadas) devem apresentar, no máximo, $5,0 \times 10^{2}$ coliformes fecais/g e devem ter ausência de Salmonella em $25 \mathrm{~g}$ de produto.

Tabela 13. NMP de coliformes totais, em tangor 'Murcott' minimamente processado armazenado a $6^{\circ}$ e $12^{\circ} \mathrm{C}$, utilizando-se a metodologia de tubos múltiplos

\begin{tabular}{lcccc}
\hline Recobrimentos & Dias de armazenamento a $6^{\circ} \mathrm{C}$ & Dias de armazenamento a $12^{\circ} \mathrm{C}$ \\
Comestíveis & 4 & 7 & 4 & 7 \\
\hline Controle & ausência & ausência & ausência & ausência \\
Gelatina 8\% & ausência & ausência & ausência & ausência \\
Gelatina 4\% & ausência & ausência & ausência & ausência \\
Soro de leite 8\% & ausência & ausência & ausência & ausência \\
Parafina & ausência & ausência & ausência & ausência
\end{tabular}

Os resultados obtidos representam o NMP de coliformes totais/g de produto.

Tabela 14. NMP de coliformes fecais, em tangor 'Murcott' minimamente processado armazenado a $6^{\circ}$ e $12^{\circ} \mathrm{C}$, utilizando-se a metodologia de tubos múltiplos

\begin{tabular}{lcccc}
\hline Recobrimentos & Dias de armazenamento a $6^{\circ} \mathrm{C}$ & Dias de armazenamento a $12^{\circ} \mathrm{C}$ \\
Comestíveis & 4 & 7 & 4 & 7 \\
\hline Controle & ausência & ausência & ausência & ausência \\
Gelatina 8\% & ausência & ausência & ausência & ausência \\
Gelatina 4\% & ausência & ausência & ausência & ausência \\
Soro de leite 8\% & ausência & ausência & ausência & ausência \\
Parafina & ausência & ausência & ausência & ausência \\
\hline
\end{tabular}

Os resultados obtidos representam o NMP de coliformes fecais/g de produto. 
Tabela 15. Detecção de Salmonella em 25g de tangor 'Murcott' minimamente processado armazenado a $6^{\circ}$ e $12^{\circ} \mathrm{C}$, utilizando-se o kit "1-2 test" da BioControl/USA

\begin{tabular}{lcccc}
\hline Recobrimentos & Dias de armazenamento a $6^{\circ} \mathrm{C}$ & \multicolumn{2}{c}{ Dias de armazenamento a $12^{\circ} \mathrm{C}$} \\
Comestíveis & 4 & 7 & 4 & 7 \\
\hline Controle & ausência & ausência & ausência & ausência \\
Gelatina 8\% & ausência & ausência & ausência & ausência \\
Gelatina 4\% & ausência & ausência & ausência & ausência \\
Soro de leite 8\% & ausência & ausência & ausência & ausência \\
Parafina & ausência & ausência & ausência & ausência \\
\hline
\end{tabular}

\subsubsection{Análise sensorial}

A Tabela 16 apresenta os dados da avaliação sensorial para tangor 'Murcott' minimamente processado. Pode-se verificar que os recobrimentos não influenciaram a aparência dos frutos armazenados a $6^{\circ} \mathrm{C}$ e nem dos a $12^{\circ} \mathrm{C}$.

Os provadores relataram que as amostras recobertas com concentrado protéico de soro de leite apresentaram odor estranho e compararam-no ao odor de ovo, o que fica evidente nas amostras armazenadas a $12^{\circ} \mathrm{C}$, onde as amostras tratadas com soro de leite apresentaram odor pior que as demais (Tabela 16). A diferença que estabelece significância entre os totais das somas de ordenação segundo a tabela de Newell e Mac Farlene (1987), citado por Silva (1997) é de $28(\mathrm{p} \leq 0,05)$.

As amostras tratadas com as duas concentrações de gelatina e o tratamento controle apresentaram sabor significativamente melhor que o das amostras tratadas com parafina (Tabela 16). Alguns provadores relataram que as amostras com parafina possuíam sabor de plástico, e outros, de parafina, o que piora o sabor das amostras e mascara o sabor característico dos frutos. 
Tabela 16. Resultados da análise sensorial através do teste de ordenação para tangor 'Murcott' minimamente processado tratado com recobrimentos comestíveis e armazenado sob duas temperaturas ${ }^{1}$

\begin{tabular}{llccccc}
\hline & & \multicolumn{5}{c}{ Recobrimentos comestíveis } \\
$\mathrm{T}^{\circ} \mathrm{C}^{2}$ & Atributos & Controle & Gelatina 8\% & Gelatina 4\% & Soro de leite 8\% & Parafina \\
\hline \multirow{2}{*}{$6^{\circ} \mathrm{C}$} & aparência & $53 \mathrm{a}$ & $62 \mathrm{a}$ & $50 \mathrm{a}$ & $68 \mathrm{a}$ & $67 \mathrm{a}$ \\
& odor & $50 \mathrm{ab}$ & $56 \mathrm{ab}$ & $45 \mathrm{~b}$ & $75 \mathrm{a}$ & $74 \mathrm{a}$ \\
& sabor & $52 \mathrm{~b}$ & $51 \mathrm{~b}$ & $49 \mathrm{~b}$ & $62 \mathrm{ab}$ & $86 \mathrm{a}$ \\
$12^{\circ} \mathrm{C}$ & aparência & $51 \mathrm{a}$ & $59 \mathrm{a}$ & $51 \mathrm{a}$ & $74 \mathrm{a}$ & $65 \mathrm{a}$ \\
& odor & $52 \mathrm{~b}$ & $52 \mathrm{~b}$ & $47 \mathrm{~b}$ & $89 \mathrm{a}$ & $60 \mathrm{~b}$
\end{tabular}

Totais seguidos pela mesma letra na linha não diferem entre si $(p \leq 0,05)$.

${ }^{1}$ Os valores representam a soma das notas das ordens atribuídas para cada tratamento. Quanto menor o valor da soma, melhor é a amostra.

${ }^{2}$ temperatura.

\subsection{Considerações gerais}

Os recobrimentos estudados neste trabalho apresentaram pouco potencial de uso em tangor 'Murcott' minimamente processado.

A emulsão de parafina foi efetiva em reduzir a atividade respiratória dos frutos somente quando estes foram armazenados a $12^{\circ} \mathrm{C}$. Além disso, este recobrimento aumentou a contagem microbiana do produto.

O concentrado protéico de soro de leite, apesar de ter conferido menor contagem microbiana às amostras, apresentou odor que foi rejeitado pelos provadores.

Os recobrimentos à base de gelatina, apesar de apresentarem um bom desempenho na análise sensorial, tiveram pouca influência sobre as demais variáveis avaliadas. 


\subsection{Conclusões}

Através dos resultados obtidos, pode-se concluir que:

* A utilização de recobrimentos comestíveis não foi efetiva na redução da taxa respiratória para gomos de tangor 'Murcott'.

* Os recobrimentos comestíveis tiveram pouca influência na manutenção das características físico químicas de tangor 'Murcott' minimamente processado na forma de gomos.

* O recobrimento à base de parafina causou aumento no desenvolvimento de microorganismos em tangor 'Murcott' minimamente processado e o recobrimento à base de concentrado protéico de soro de leite causou discreta redução.

* Tangores 'Murcott' minimamente processados sem recobrimento ou recobertos com concentrado protéico de soro de leite ou gelatina a $8 \%$ apresentaram-se em condição de consumo por 7 dias a $6^{\circ}$ ou $12^{\circ} \mathrm{C}$.

* Os recobrimentos comestíveis foram pouco efetivos na manutenção das características sensoriais de tangor 'Murcott' minimamente processado. 


\section{CONCLUSÕES GERAIS}

* A injúria causada pelo processamento mínimo aumenta a taxa respiratória de tangor 'Murcott'.

- A elevação da temperatura de armazenamento em $10^{\circ} \mathrm{C}$ aumenta a taxa respiratória de tangor 'Murcott' minimamente processado em até 2,6 vezes.

- Tangores 'Murcott' minimamente processados sem recobrimento ou recobertos com concentrado protéico de soro de leite ou gelatina a $8 \%$ apresentaram-se em condição de consumo por 7 dias a $6^{\circ}$ ou $12^{\circ} \mathrm{C}$.

* O uso de recobrimentos comestíveis a base de gelatina, concentrado protéico de soro de leite e parafina são pouco efetivos na manutenção das características fisiológicas, físico-químicas, microbiológicas e sensoriais de tangor 'Murcott' minimamente processado. 
ANEXOS 
ANEXO A - Resumo do quadro de análise de variância para as variáveis ácido ascórbico (ác asc), sólidos solúveis (ss), acidez titulável (at), pH, "ratio" e perda de massa fresca (massa)

\begin{tabular}{|c|c|c|c|c|c|c|c|}
\hline \multicolumn{2}{|l|}{ Causas de } & \multicolumn{6}{|c|}{ Quadrado médio } \\
\hline variação & GL & ác asc & ss & at & $\mathrm{pH}$ & "ratio" & Massa \\
\hline Recobrimento (R) & 4 & 7,22 & $3,94^{* *}$ & 0,01 & 0,01 & $22,54^{* *}$ & $0,47^{* *}$ \\
\hline Temperatura (Te) & 1 & 9,47 & 0,05 & 0,01 & $0,22^{* *}$ & $20,67^{*}$ & $1,43^{* *}$ \\
\hline Tempo (To) & 3 & $299,20 * *$ & 0,40 & $0,06^{* *}$ & $0,90^{* *}$ & $51,19^{* *}$ & $45,51^{* *}$ \\
\hline $\mathrm{R} \times \mathrm{Te}$ & 4 & 5,58 & $1,20^{* *}$ & $0,02^{* *}$ & $0,03^{*}$ & $28,71^{* *}$ & 0,01 \\
\hline $\mathrm{R} \times \mathrm{To}$ & 12 & $9,20^{*}$ & $0,57^{*}$ & 0,004 & 0,01 & 6,75 & $0,12^{*}$ \\
\hline Te $\times$ To & 3 & $17,55^{\star}$ & 0,02 & 0,01 & 0,02 & 10,15 & $0,23^{* *}$ \\
\hline $\mathrm{R} \times \mathrm{Te} \times \mathrm{To}$ & 12 & 2,71 & 0,31 & 0,005 & 0,01 & 8,51 & 0,003 \\
\hline Resíduo & 120 & 4,67 & 0,29 & 0,004 & 0,01 & 5,19 & 0,05 \\
\hline TOTAL & 159 & & & & & & \\
\hline CV (\%) & & $9,88 \%$ & $4,46 \%$ & $10,12 \%$ & $2,86 \%$ & $11,06 \%$ & $20,50 \%$ \\
\hline
\end{tabular}

ANEXO B - Resumo do quadro de análise de variância para as variáveis luminosidade (L) e cromaticidade (C)

\begin{tabular}{lccc}
\hline Causas de variação & GL & $\mathrm{L}$ & Quadrado médio \\
\hline Recobrimento (R) & 4 & 8,42 & 1,22 \\
Temperatura (Te) & 1 & 0,0001 & 0,004 \\
Tempo (To) & 3 & $45,14^{* *}$ & $351,42^{\star *}$ \\
R x Te & 4 & 6,92 & 1,28 \\
R x To & 12 & 9,26 & 0,34 \\
Te x To & 3 & 10,53 & 0,31 \\
R x Te x To & 12 & 7,86 & 1,55 \\
Resíduo & 120 & 9,36 & 2,09 \\
TOTAL & 159 & & \\
CV (\%) & & $7,63 \%$ & $4,67 \%$ \\
\hline
\end{tabular}

* significativo $p \leq 0,05 ;{ }^{* *}$ significativo $p \leq 0,01$ 
ANEXO C - Modelo da ficha de avaliação sensorial

FICHA DE AVALIAÇÃO PARA ANÁLISE SENSORIAL DE 'MURCOTT' MINIMAMENTE PROCESSADA

Nome:

Telefone: Data:

Muito obrigado por participar de nossa pesquisa com 'Murcott' minimamente processada. Você está recebendo 5 amostras de 'Murcott' para avaliar a aparência, o odor e o sabor do produto.

Por favor, prove as amostras da esquerda para a direita. Ordene as amostras em ordem decrescente em relação aos atributos avaliados.

\section{APARÊNCIA}

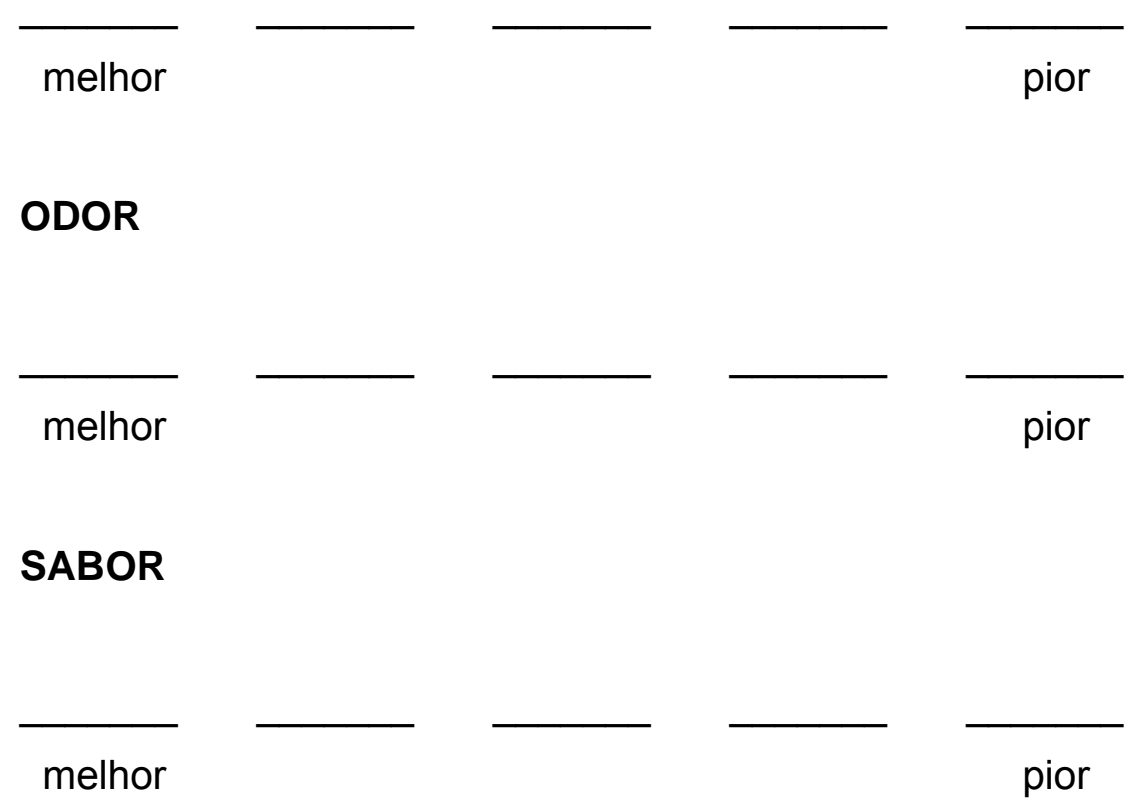




\section{REFERÊNCIAS BIBLIOGRÁFICAS}

AGÊNCIA NACIONAL DE VIGILÂNCIA SANITÁRIA. Resolução - RDC $\mathbf{n}^{\circ} \mathbf{1 2}$, de 02 de janeiro de 2001. www.anvisa.gov.br/legis/resol/12_01rdc.htm (08 nov. 2004).

AHVENAINEN, R. New approaches in improving the shelf life of minimally processed fruit and vegetables. Trends in Food Science \& Technology, v.7, p.179-187, 1996.

ARPAIA, M.L.; KADER, A.A. Produce facts: mandarin - tangerine; recommendations for maintaining postharvest quality. Davis: University of California, Postharvest Technology Research and information Center, 1999. 2p. (Perishables Handling, 98).

ARRUDA, M.C. Processamento mínimo de melão rendilhado: tipo de corte, temperatura de armazenamento e atmosfera modificada. Piracicaba, 2002. 71p. Dissertação (Mestrado) - Escola Superior de Agricultura "Luiz de Queiroz", Universidade de São Paulo. 
BAKER, R.A.; HAGENMAIER, R.D. Reduction of fluid loss from grapefruit segments with wax microemulsion coatings. Journal of Food Science, v.62, n.4, p.789-792, 1997.

BALDWIN, E.A.; NISPEROS-CARRIEDO, M.O.; BAKER, R.A. Edible coatings for lightly processed fruits and vegetables. HortScience, v.30, n.1, p.35-38, 1995a.

BALDWIN, E.A.; NISPEROS-CARRIEDO, M.O.; BAKER, R.A. Use of edible coatings to preserve quality of lightly (and slightly) processed products. Critical Reviews in Food Science and Nutrition, v.65, n.6, p.509-524, 1995b.

BRECHT, J.K. Physiology of lightly processed fruits and vegetables. HortScience, v.30, n.1, p.18-22, 1995.

BURNS, J.K. Lightly processed fruits and vegetables: Introduction to the Colloquium. HortScience, v.30, n.1, p.14-17, 1995.

CAMARGO, A.M.M.P.C.; CASER, D.V.; FRANCISCO, V.L.F.S.; GHOBRIL, C.N. Previsões e estimativas das safras agrícolas do Estado de São Paulo, ano agrícola 2001/02, novembro 2001. Informações Econômicas, v.32, n.2, p.106, 2002. 
CANTWELL, M. Postharvest handling systems: minimally processed fruit and vegetables. In: KADER, A.A. (Ed.). Postharvest technology of horticultural crops. 2.ed. Davis: University of California, Dir. Agric. Nat. Res., 1992. p.277-281. (Publication, 3311).

CARVALHO, C.R.L.; MANTOVANI, D.M.B.; CARVALHO, P.R.N.; MORAES, R.M.M. Análises químicas de alimentos. Campinas: ITAL, 1990.121p. (ITAL. Manual Técnico).

CHEN, H. Functional properties and applications of edible films made of milk proteins. Journal of Dairy Science, v.78, p.2563-2583, 1995.

CHITARRA, M.I.F. Processamento mínimo de frutos e hortaliças. Viçosa: Centro de Produções Técnicas, 1998. 88p.

CHITARRA, M.I.F.; CHITARRA, A.B. Pós-colheita de frutos e hortaliças: fisiologia e manuseio. Lavras: ESAL, Fundação de Apoio ao Ensino, Pesquisa e Extensão, 1990. 293p.

CISNEROS-ZEVALLOS, L.; KROCHTA, J.M. Internal modified atmospheres of coated fresh frits and vegetables: understanding relative humidity effects. Journal of Food Science, v.67, n.8, p.2792-2797, 2002.

DAVIES, F.S.; ALBRIGO, L.G. Crop production in horticulture 2. Citrus. London: CAB INTERNATIONAL, 1994. 254p. 
DONADON J.R.; DURIGAN, J.F.; SOUZA, B.S.; SANCHES, J.; MIGUEL, A.C.A. Atividade respiratória de tangerinas Murcote intactas e minimamente processadas armazenadas sob diferentes temperaturas. Brazilian Journal of Plant Physiology, v.16, p.13, 2004. Suplemento. /Apresentado ao 1. Workshop Internacional de Pós-colheita de Frutas, Cordeirópolis, 2004 Resumo/.

DURIGAN, J.F.; SARGENT, S.A. Uso do melão Cantaloupe na produção de produtos minimamente processados. Alimentos e Nutrição, v.10, p.69-77, 1999.

FAKHOURI, F.M.; GROSSO, C. Efeito de coberturas comestíveis na vida útil de goiabas in natura (Psidium guajava L.) mantidas sob refrigeração. Brazilian Journal of Food Technology, v.6, n.2, p.203-211, July/Dec. 2003.

FANG, Y.; TUNG, M.A.; BRITT, I.J., YADA, S.; DALGLEISH, D.G. Tensile and barrier properties of edible films made from whey proteins. Journal of Food Science, v.67, p.188-193, 2002.

FIGUEIREDO, J.O.de. Variedades copa de valor comercial. In: RODRIGUÉZ, O.; VIEGAS, F.; POMPEU JÚNIOR, J.; AMARO, A.A. (Ed.). Citricultura brasileira. 2.ed.Campinas: Fundação Cargill, 1991.v.1, p.228-264.

FNP CONSULTORIA \& COMÉRCIO. Agrianual 2000: anuário da agricultura brasileira. São Paulo, 2000.p.34-45: Horticultura.

FNP CONSULTORIA \& COMÉRCIO. Agrianual 2003: anuário da agricultura brasileira. São Paulo, 2002. p.295-332: Laranja. 
GENNADIOS, A.; McHUGH, T.H.; WELLER, C.L.; KROCHTA, J.M. Edible coatings and films based on proteins. In: KROCHTA, J.M.; BALDWIN, E.A.; NISPEROS-CARRIEDO, M.O. (Ed.). Edible coatings and films to improve food quality. Lancaster: Technomic Publishing Company, 1994. cap.9, p.201-277.

HAJDENWURCEL, J.R. Atlas de microbiologia de alimentos. São Paulo: Fonte, 1998. 66p.

HERNANDEZ, E. Edible coatings from lipids and resins. In: KROCHTA, J.M.; BALDWIN, E.A.; NISPEROS-CARRIEDO, M.O. (Ed.). Edible coatings and films to improve food quality. Lancaster: Technomic Publishing Company, 1994. cap.10, p.279-303.

HILDEBRAND, D. F. Lipoxygenases. Physiologia Plantarum, v.76, n.2, p.249253, June 1989.

HIRAUSHI, A.; HORIE, S.Species composition and growth temperature characteristics of coliforms in relation to their sources. Journal of General Applied Microbiology, v,28, p.139-154, 1982.

HURST, W.C. Sanitation of lightly processed fruits and vegetables. HortScience. v. 30, n.1, p.22-24, 1995.

INTERNATIONAL COMMISSION ON MICROBIOLOGICAL SPECIFCATIONS FOR FOODS. Microorganisms in foods. 2.ed. Toronto: University of Toronto Press, 1978. v.1, 434p. 
INTERNATIONAL FRESH PRODUCT ASSOCIATION. Fresh-cut produce handling guidelines. 3. ed. Newark: Produce Marketing, 1999. 39p.

KADER, A.A. Postharvest biology and technology: an overview. In: KADER, A.A. (Ed.). Postharvest technology of horticultural crops. 2.ed. Davis: University of California, Dir. Agric. Nat. Res., 1992. p.15-20. (Publication, 3311).

KESTER, J.J.; FENNEMA, O.R. An edible film of lipids and cellulose ethers: barriers properties to moisture vapor transmission and structural evaluation. Journal of Food Science. v.54, n.6, p. 1383-1389, 1989.

KING, A.D.; BOLIN, H.R. Physiological ans microbiological storage stability of minimally processed fruits and vegetables. Food Technology, p.132-135, Feb. 1989.

KOLLER, O.C. Citricultura: laranja, limão e tangerina. Porto Alegre: Editora Rigel, 1994.446p.

LAMIKANRA, O.; CHEN, J.C.; BANKS, D.; HUNTER, P.A. Biochemical and microbial changes during the storage of minimally processed cantaloupe. Journal of Agricultural and Food Chemistry. v.48, p.5955-5961, 2000.

LUENGO, R.F.A.; LANA, M.M. Processamento mínimo de hortaliças. Brasília: EMBRAPA, 1997. 4p. (EMBRAPA. Comunicado Técnico, 2). 
MORETTI, C.L. Processamento mínimo de hortaliças: alternativa viável para a redução de perdas pós-colheita e agregação de valor ao agronegócio brasileiro. Horticultura Brasileira, v.17, n.2, p.1, 1999.

NGUYEN-the, C.; CARLIN, F. The microbiology of minimally processed fresh fruits and vegetables. Critical Reviews in Food Science and Nutrition, v.34, n.4, p. 371-401, 1994.

OLIVEIRA, M.A. Utilização de película de fécula de mandioca como alternativa à cera comercial na conservação pós-colheita de frutos de goiaba (Psidium guajava). Piracicaba, 1996. 73p. Dissertação (Mestrado) - Escola Superior de Agricultura "Luiz de Queiroz", Universidade de São Paulo.

PAO, S.; PETRACEK, P.D. Shelf life extension of peeled oranges by citric acid treatment. Food Microbiology, v.14, p.485-491, 1997.

PRETEL, M.T.; LOZANO, P.; RIQUELME, F.; ROMOJARO, F. Pectic enzymes in fresh fruit processing: optimization of enzymic peeling of oranges. Process Biochemistry, v.32, n.1, p. 43-49, 1997.

ROCHA, A.M.C.N.; BROCHADO, C.M.; KIRBY, R.; MORAIS, A.M.M.B. Shelflife of chilled cut orange determined by sensory quality. Food Control, v.6, n.6, p. 317-322, 1995.

ROSEN, J.; KADER, A. A. Postharvest physiology and quality maintenance of sliced pear and strawberry fruits. Journal of Food Science, v.54, p.656-659, 1989.

SILVA, M.A.A.P. Métodos de avaliação sensorial de alimentos. Campinas: Escola de Extensão da UNICAMP, 1997. 71p. 
VAROQUAUX, P.; WILEY, R.C. Biological and biochemical changes in minimally processed refrigerated fruits and vegetables. In: WILEY, R.C. Minimally processed refrigerated fruits and vegetables. New York: Chapman \& Hall, 1994. 368p.

VILAS BOAS, E.V.B.; PINHEIRO, A.C.M.; PRADO, M.E.T.; MATTOS, L.M.; SANTOS, J.C.B.; LIMA, L.C.O. Efeito do descascamento sobre a qualidade de tangerinas 'Ponkan'. In: ENCONTRO NACIONAL SOBRE PROCESSAMENTO MÍNIMO DE FRUTAS E HORTALIÇAS, 2., Viçosa, 2000. Resumos. Viçosa: UFV, 2000. p.23

VITTI, M.C.D.; KLUGE, R.A.; BASSETO, E.; JACOMINO, A.P. Temperatura de armazenamento de tangores "Murcote" minimamente processados. Revista Brasileira de Fruticultura, v.25, n.3, p. 535-536, 2003.

WATADA, A. E.; QI, L. Quality of fresh-cut produce. Postharvest Biology and Technology, v.15, p.201-205, 1999.

WATADA, A.E.; KO, N.P.; MINOTT, D.A. Factors affecting quality of fresh-cut horticultural products. Postharvest Biology and Technology, v.9, p.115$125,1996$.

WILEY, R.C. Minimally processed refrigerated fruits and vegetables. New York: Chapman \& Hall, 1994. 368p.

YONG, H.H. Gelatin. In: MARK, H.F.; GAYLORD, N.G.; BIKALES, N.M. (Ed.) Encyclopedia of polymer science and technology: plastics, resins, rubbers, fibers. New York: Interscience Publishers, 1967. p.446-460. 